Article

\title{
Oxygen Gradients and Structure of the Ciliate Assemblages in Floodplain Lake
}

\author{
Roman Babko ${ }^{1, *}$, Tetiana Kuzmina ${ }^{2}$, Yaroslav Danko ${ }^{3} \mathbb{D}$, Joanna Szulżyk-Cieplak ${ }^{4}$ (D) \\ and Grzegorz Łagód ${ }^{5}$ (i)
}

1 Department of Invertebrate Fauna and Systematics, Schmalhausen Institute of Zoology NAS of Ukraine, 01030 Kyiv, Ukraine

2 Faculty of Technical Systems and Energy Efficient Technologies, Sumy State University, 40007 Sumy, Ukraine; t.kuzmina@ecolog.sumdu.edu.ua

3 Faculty of Natural Sciences and Geography, Sumy Makarenko State Pedagogical University, 40002 Sumy, Ukraine; yaroslavdanko@gmail.com

4 Fundamentals of Technology Faculty, Lublin University of Technology, 20-618 Lublin, Poland; j.szulzyk-cieplak@pollub.pl

5 Faculty of Environmental Engineering, Lublin University of Technology, 20-618 Lublin, Poland; g.lagod@pollub.pl

* Correspondence: rbabko@ukr.net

Received: 23 May 2020; Accepted: 17 July 2020; Published: 23 July 2020

\begin{abstract}
This paper presents the results of studies on the structure of the ciliate population in a freshwater lake. The classification of the ciliated communities based on the analysis of the distribution of ciliate population density in the lake along the oxygen gradients, taking into account their oxygen preferences, was proposed. It was shown that the distribution of ciliated protozoa in the space of a reservoir is determined not by such spatial units as the water column, bottom, and periphytal, but by the oxygen gradients. Four types of habitats with different oxygen regimes were distinguished: With stably high oxygen concentration, stably low oxygen concentration, stably oxygen-free conditions, and conditions with a high amplitude of diurnal oxygen variations. The location of these habitats in the space of the lake and their seasonal changes were determined. On the basis of the quantitative development of ciliate populations, zones of optima and tolerance ranges of some ciliate species in the oxygen gradient were established. The oxygen preferences were established for the species from four distinguished assemblages: Microoxyphilic, oxyphilic, euryoxyphilic, and anoxyphilic (anaerobic). The presence or the absence of a certain type of assemblage in the reservoirs depends solely on the parameters of the oxygen gradients. The diversity of the ciliated protozoa in water bodies also depends on the stability and diversity of the oxygen gradients.
\end{abstract}

Keywords: ciliate assemblages; oxygen concentration; ecological optimum; lake; freshwater habitats

\section{Introduction}

Ciliates are one of the diverse groups of protozoa; today about 1500 morphospecies of freshwater ciliates have been described [1]. However, according to forecasts, the total diversity of these unicellular organisms can reach from 12 to 40 thousand species [2,3]. The diversity of ciliated protozoa on a global scale is fairly uniform. Nevertheless, numerous studies show that in some territories, and in water bodies of different types, the diversity of ciliated protozoa differ significantly [4-12]. Compared to the potential diversity, the realized diversity is dynamic and reflects the specific conditions of each water body, leading to the dissimilarity of the fauna. This local diversity remains unpredictable and varies in space and time. Nevertheless, it has been successfully used to assess the status of aquatic ecosystems. In assessing the species diversity in a separate time-limited study, only a small fraction of the available 
genetic potential ("seedbank of protozoan") is usually detected [1]. Assessing the local diversity of even a small, one-hectare pond can never be complete [13]. Obtaining reliable information about the local diversity of ciliates remains a problem. It depends on the duration of the studies, season coverage, the geographical location of the reservoir, and so on. The number of identified species is also affected by the number of samples taken, the frequency of sampling, the number and variety of the examined habitats, etc. Obviously, an effective study of the diversity of protozoa also depends on our ideas about their structural organization in the hyperspace of water bodies.

Despite a significant number of studies, they are not enough to predict the local diversity of ciliated protozoa, its changes in time and its relation to the type of reservoir. The assessment of diversity remains problematic due to the conservatism of ideas about the nature of species distribution. Namely, most studies proceed from the idea that the ciliate population is structured according to the traditional biotopes: Pelagial, benthal, periphytal [4,14-23].

At the same time, it has been shown quite convincingly that the ciliated protozoa are very sensitive to the concentration of oxygen dissolved in water [24,25]. Nevertheless, the oxygen gradients are far from being always taken into account when studying the diversity of protozoa and assessing the state of the ecosystem of a reservoir. In most cases, the traditional approach is prevailing in dividing the space of a reservoir into listed biotopes, although the conditions, including the concentration of oxygen, within each biotope may be heterogeneous [24].

This makes it relevant to analyze the spatial distribution of the ciliated protozoa without reference to the classical biotopes, particularly, to study the structure of the population of ciliates in the context of their reaction to the oxygen gradients.

In this regard, the aim of our work was to generalize the results of two-year studies on the ciliated protozoa under the conditions of a floodplain lake in the context of their spatial organization and the relationship of this organization with the oxygen gradients that existed in different parts of the water body, regardless of its traditional separation into the classical biotopes.

\section{Materials and Methods}

\subsection{Study Area}

The authors studied the distribution of ciliated protozoa in water in a floodplain eutrophic lake. The floodplain lake is located on the right bank of the Vorskla River in the Sumy Oblast (Ukraine). The lake stretches from northwest to southeast approximately parallel to the modern channel of the Vorskla River. Table 1 shows the location, morphometric data of the lake, and selected water quality indicators.

Table 1. Geographical location and characteristics of the lake.

\begin{tabular}{cc}
\hline Parameters & Values \\
\hline Location & $50.313942,34.839761$ \\
Area, $\mathrm{m}^{2}$ & 21,300 \\
Length, $\mathrm{m}$ & 400.0 \\
Maximum width, $\mathrm{m}$ & 59.5 \\
Maximum depth, $\mathrm{m}$ & 8.5 \\
Secchi depth, $\mathrm{m}$ & $0.7-1.0$ \\
$\mathrm{pH}$ & $8.15-8.30$ \\
Permanganate index, $\mathrm{mg} \mathrm{O}_{2} / \mathrm{L}$ & $7.8-15.0$ \\
\hline
\end{tabular}

The lake is located $100 \mathrm{~m}$ from the main channel of the river and during periods of high water-mainly in the spring during floods-is connected to the main channel by a narrow channel, which dries up in summer. The lake never completely dries up. In the low-water period (summer), the maximum depth is 8-8.5 m. Macrophyte thickets were formed by Phragmites australis (Cav.) Trin. ex Steudel, Ceratophyllum demersum L., Lemna minor L., Spirodela polyrrhiza (L.) Schleid., Nuphar lutea (L.) 
Sibth. \& Sm. Samples from each type of habitat were taken at five points (places). The lake and the localization of sampling stations are shown in Figure 1.

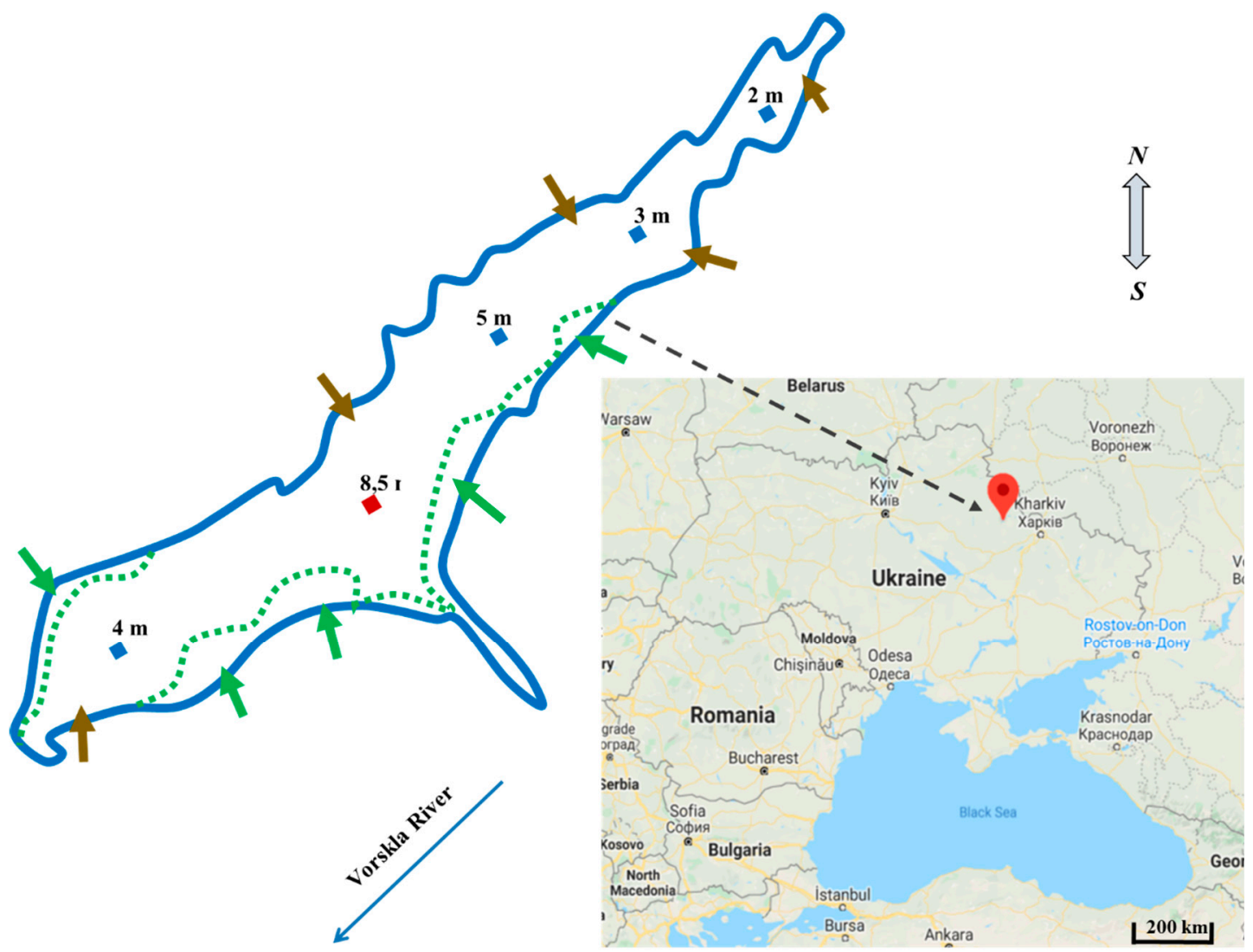

Figure 1. Location of the study area and sampling points. The green arrows indicate the places of sampling of plants, the brown arrows indicate the places of sampling of bottom sediments in the littoral, the rhombuses indicate the places of sampling of water and bottom sediments in the pelagial and profundal, the red rhombus indicates the place of the maximum depth of the lake. The dashed green line shows littoral sections of macrophyte thickets.

In the littoral, samples of bottom sediments were taken at a depth of 0.5 to $1.5 \mathrm{~m}$ depending on the slope of the bottom, usually at a distance of $1 \mathrm{~m}$ from the water edge. Plant samples were taken from the central part of the plant spot at a depth of about $0.5 \mathrm{~m}$. Metaphyton samples were taken at a distance of $0.5-1.0 \mathrm{~cm}$ from the plant shoots at a depth of $0.5 \mathrm{~m}$.

\subsection{Habitats}

In spring and autumn, water turnover was observed in the lake. In winter, during the ice cover, anaerobic conditions were observed in the lake in almost the entire water column. From June to September, a distinct temperature stratification is observed in the lake. In the water column during this period, three habitats that differ in the oxygen content can be distinguished. The epilimnion has a high oxygen content of up to $13 \mathrm{mg} / \mathrm{L}$ and a layer of water from the surface to a depth of $1-1.5 \mathrm{~m}$. The metalimnion has an oxygen content of from 0 to $3 \mathrm{mg} / \mathrm{L}$ and a layer from 1.5 to $4.0 \mathrm{~m}$. In the upper part of the metalimnion at a depth of 1.5 to $2.5 \mathrm{~m}$, an accumulation of detritus is observed. There is a sharp decrease in the oxygen concentration here to $0-1 \mathrm{mg} / \mathrm{L}$. The hypolimnion was anoxic.

According to the bottom profile, two different habitats are distinguished: The bottom in the littoral zone, represented by silted sand with detritus, with a low oxygen content of 0 to $3 \mathrm{mg} / \mathrm{L}$; and the bottom in the profundal zone with sapropel deposits and anoxic conditions. The difference between 
these two habitats is that in the profundal zone oxygen is always absent, and in the silted sand the conditions range from microaerophilic to anaerobic.

Periphytal, the surface of the plants and metaphytal, the water among the thickets of plants, were considered as separate habitats. Both in the layer of water near the plants' surface and-to a lesser extent-in the metaphytal, the oxygen content varied drastically over the course of the day: From 0 to $250 \%$ of saturation. Oxygen surges (high amplitude of diurnal fluctuations in the oxygen content) were the main difference between these habitats and all others, where the oxygen content did not change significantly during the day.

\subsection{Sampling Methods and Calculations}

The samples for counting of ciliates were taken in all of the habitats. Samples from the water column $(1.0 \mathrm{~L})$ were taken by a Rutner bathometer. At each of the five stations, samples were taken every $0.5 \mathrm{~m}$ vertically. The sampling of the bottom sediments was carried out with a microbentometer [26]. Using it, the sediment cores of a cylindrical shape with an area of $7 \mathrm{~cm}^{2}$ and a length of up to $6 \mathrm{~cm}$ were taken. For analysis of bottom samples from littoral, a 1-cm layer of bottom sediments and a 3-cm layer of water above the bottom, where oxygen was recorded, were treated as a single sample. The layer of bottom sediments below $3 \mathrm{~cm}$ depth, where there was no oxygen, was detached and examined as a separate sample. The water samples from the thickets of plants were taken with a syringe (volume $200 \mathrm{~mL}$, hole diameter $4 \mathrm{~mm}$ ) onto which instead of a needle, a plastic tube of the corresponding diameter was installed. The plant samples were taken using a glass tube with a diameter of $3.5 \mathrm{~cm}$, which was carefully draw on the shoot of the plant; the shoot was cut off, afterwards the tube was closed up on both sides (Figure 2a-c) [10]. Semi-submerged plants were previously cut off above the surface of the water, and a sample was taken, truncating part of the underwater leaf or stem and enclosing it in a glass tube. Samples of floating plants (duckweed) were taken by passing a glass tube along the surface covered with duckweed plants; after the tube was closed on both sides (Figure 2d). Samples of anaerobic sediments (sapropel) and samples from oxygen free hypolimnion were taken and sealed in containers without contact with oxygen. Oxygen-free samples were opened only at the time of sub-sampling.

The studies were carried out in full in the first and last decade of each month. In each habitat, temperature and $\mathrm{O}_{2}$ measurements were carried out using a $\mathrm{HACH} \mathrm{HQ} 40 \mathrm{~d}$ portable multi-meter with a sensor attached to a $10 \mathrm{~m}$ cable. Oxygen measurements in all environments were performed before each sampling. Each time vertical sampling using the HACH HQ40d multi-meter, oxygen and temperature were measured from the surface to the bottom. The distribution of these parameters by depths were established. Seasonal averages are shown in graphs.

To establish the permanganate index, a part of the sample taken by a bathometer from each depth was used. When sampling plants, metaphyton, and bottom, a sample for the permanganate index was taken in the same place with a $100 \mathrm{~mL}$ syringe.

The samples were transported to the laboratory, where they were immediately processed. During the analysis of the sub-samples, the main samples were kept in the refrigerator at a temperature of $+5^{\circ} \mathrm{C}$, which ensured the maximum preservation of quantitative ratios of populations.

In the quantitative treatment of samples, the abundance of ciliates was determined in their actual living space (ALS). By actual living space, we mean part of the volume of the water body in which the population of a given species is recorded. This can be the entire pelagic zone (or only part of it), the water in bottom sediments, or a layer of water around the submerged surface of plants. The population may be limited in its distribution to one, or be distributed among several habitats. Moreover, as a rule, there is a habitat in which conditions correspond to their ecological optimum, while their presence in neighboring habitats is a reflection of their environmental tolerance expanding their ecological niche. Different species of plants vary significantly in the spatial organization of the surface, which creates unequal conditions for the existence of protozoa [27]. Therefore, various approaches were used for calculating of the density of protozoa to determine the volume of their ALS. 
The ALS of the protozoa on the Ceratophyllum is equal to the volume of the cylinder with the shoot diameter minus the volume of the plant itself (Figure 2). The ALS of protozoa on the plants with simple leaves such as Phragmites australis was calculated based on the surface area of the sample and the water layer $1 \mathrm{~cm}$ above the surface. For the floating plants, such as Lemna minor and Spirodela polyrrhhiza, ALS was calculated as the volume corresponding to the area of leaf blades and the length of the dropping roots. The volume of living space for the inhabitants of bottom sediments was determined by measuring the volume of water between the particles of bottom sediments. The bottom sediments were drying and re-filling it with water.
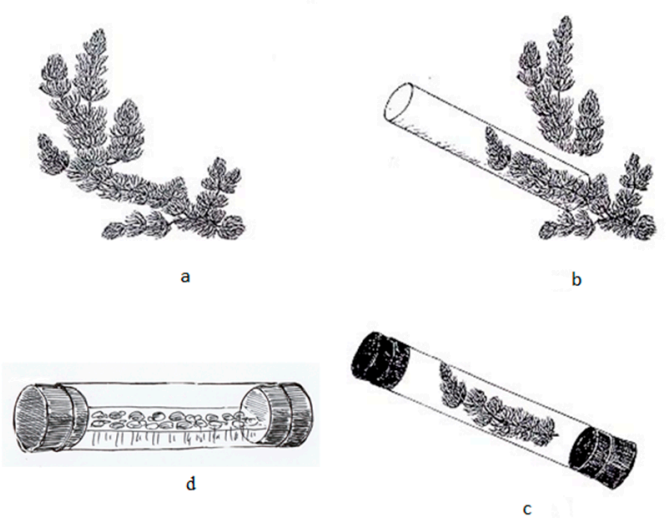

Figure 2. Sampling of periphyton on submerged macrophyte Ceratophyllum demersum: (a) The shoot of a plant; (b) the tube is put on the shoot so as to minimally disrupt its position in the water; (c) a separated shoot in the tube, ready for transfer to the laboratory; (d) sample of Lemna minor and Spirodela polyrrhiza.

From a pre-mixed sample of the water from pelagial and metaphytal, 5-7 sub-samples were taken with a sampler. The sub-sample volume was $1 \mathrm{~mL}$. Each sub-sample was transferred to a $1.5 \mathrm{~mL}$ chamber and the protozoa were counted under a binocular microscope with magnification $\times 28$ and $\times 56$. In cases of a small number of organisms-less than 3 specimens per sub-sample-the number of sub-samples was increased to 9-11. Sub-samples data were averaged.

The procedure for processing bottom sediment samples was similar. However, in the case of a high abundance of ciliates, they were counted in a drop of $25 \mu \mathrm{L}$ on a microscope slide. Subsequently, the population density was calculated per unit volume of their living space.

Laboratory processing of periphyton samples was carried out in two stages [10]. Three fragments (each about $1 \mathrm{~cm}^{2}$ ) were separated from a reed sample under water with a scalpel in a Petri dish. Each fragment was placed in a small Petri dish (diameter $5 \mathrm{~cm}$ ) and fragmented into strips with a width of about $3 \mathrm{~mm}$. On each fragment, under the magnifying glass, sessile ciliates were counted. The data were averaged over $1 \mathrm{~cm}^{2}$ and the abundance was calculated on the volume of living space for periphyton. The rest of the sample (leaf fragment) was thoroughly cleaned with a stiff brush on both sides in a large Petri dish. The fragment was removed, and its area was measured. The sample obtained by this procedure was analyzed in the same way as in the case of the water column. At this stage, crawling and swimming forms were counted. The data were averaged based on the area of the processed fragment and counted on the volume of periphyton living space- $-1 \mathrm{~cm}^{3}$. In the case of duckweed, sessile forms were counted by placing individual plants in small diameter Petri dishes with a small amount of water. Usually 9 to 11 plants were treated. The duckweed plants remaining in the sample were shredded with scissors, and the sample was mixed and analyzed in the same way as the bottom samples. The data obtained were recounted on the volume of living space based on the number of duckweed plants involved in the calculations, the sample volume, and the average root length. When calculating the population density on the hornwort, three plant fragments $1 \mathrm{~cm}$ long were placed in separate Petri dishes. The whorl of the plant with scissors or a scalpel was divided into fragments on which the sessile forms were counted. The remaining fragment of the hornwort sample 
was shredded and analyzed for crawling and swimming forms according to the previously described procedure. The obtained data were counted on the volume of living space.

Quantitative processing of samples was carried out by three specialists and took from 10 to $12 \mathrm{~h}$. As a standard, the sampling and calculation of population density was performed three times, and the results obtained over three days were averaged. Due to the fact that the quantitative processing of a significant number of samples is difficult to combine with species identification, before the start of research, during the year, the lake was studied for species diversity in various habitats.

Species identification of ciliates was carried out in vivo with an Olympus CX41 microscope in transmitted light as well as using dark field and phase contrast methods. When necessary, ciliates were stained with 1\% methyl green or silver nitrate [28]. Species identification was based on Kahl [29-32], Foissner and Berger [33], Foissner et al. [34-37], Jankowski [38], Warren [39,40], and others.

\subsection{Statistical Analysis}

Data were processed using R [41]. Hierarchical clustering was performed with hclust from core $R$ package stats, fuzzy clustering with function fanny from package cluster [42], and plotted on the plain of principal components with fviz_cluster from factoextra [43] and principal components analysis (PCA) from FactoMineR [44]. The data on abundances of each of ciliate species before PCA and clustering were transformed by dividing abundances in each sample by the total abundance of a given species in all samples. Plots were produced using ggplot2 [45].

\section{Results}

The studied eutrophic floodplain lake remains stratified from the June to the September. In winter, during the freezing period, oxygen practically disappears in the water column (Figure 3). As mentioned in the methods section, a pronounced oxygen gradient was observed in the pelagic zone of the lake, within which three zones of different $\mathrm{O}_{2}$ content were distinguished. In the profundal zone, where the bottom sediments are represented by sapropel, stable oxygen-free conditions are maintained.

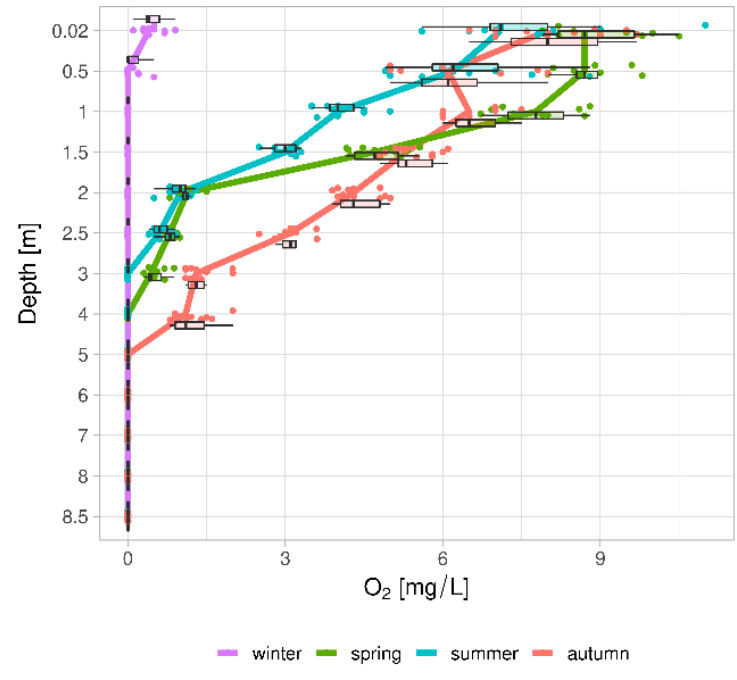

(a)

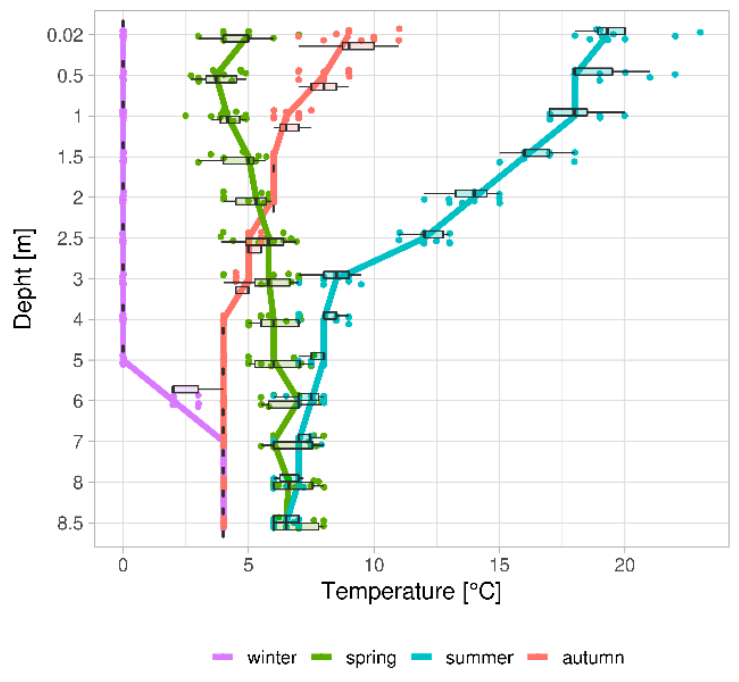

(b)

Figure 3. Vertical distribution of (a) oxygen and (b) temperature in the water column of the floodplain lake in different seasons.

The bottom sediments in the littoral zone are represented by silted sand with a low oxygen content. The oxygen content in silted sand was kept in the range from 1 to $3 \mathrm{mg}$ per liter. Deeper than 3-5 cm from the bottom surface, a stable oxygen-free zone was formed (Figure 4). 


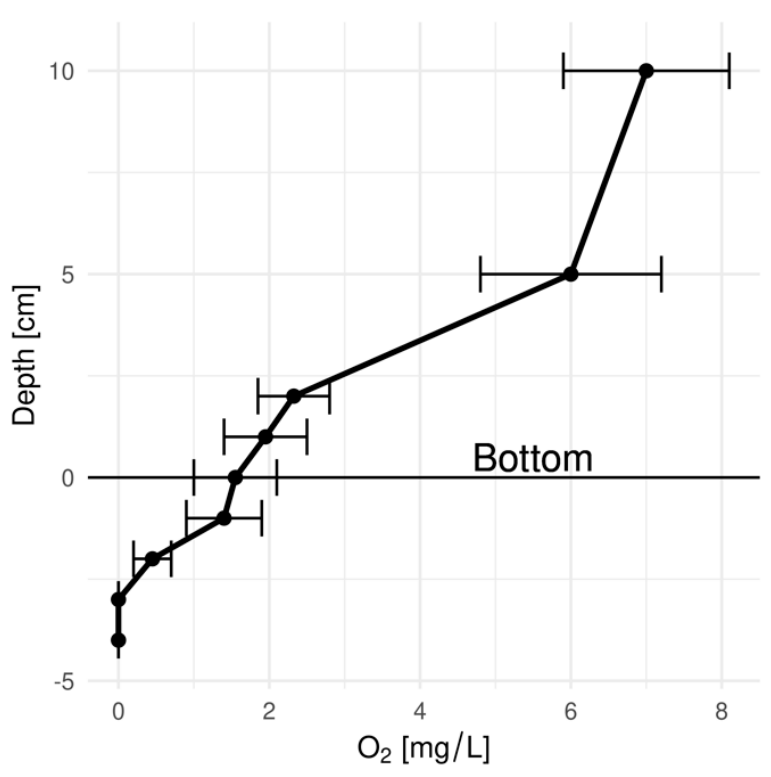

Figure 4. The oxygen content in the upper layer of the littoral sand.

In the littoral of the lake, the coastal part was overgrown with aquatic vegetation with the dominance of Ceratophyllum and Phragmites. The surface of the water between the thickets of submerged and semi-submerged vegetation is occupied by duckweeds (Lemna and Spirodela). In the thickets of aquatic vegetation, the oxygen regime was significantly different from that in the pelagic and benthic zones. As a result of fluctuations in the photosynthetic activity, the oxygen content in the thickets of plants cyclically changed within a day (Figure 5). At night, in thickets and water layers adjacent to plants (metaphytal), the respiration of plants and periphyton organisms, including bacteria, led to a decrease in the oxygen content to almost zero. At the same time, by noon, the oxygen content could reach $100-300 \%$ of the saturated concentration.

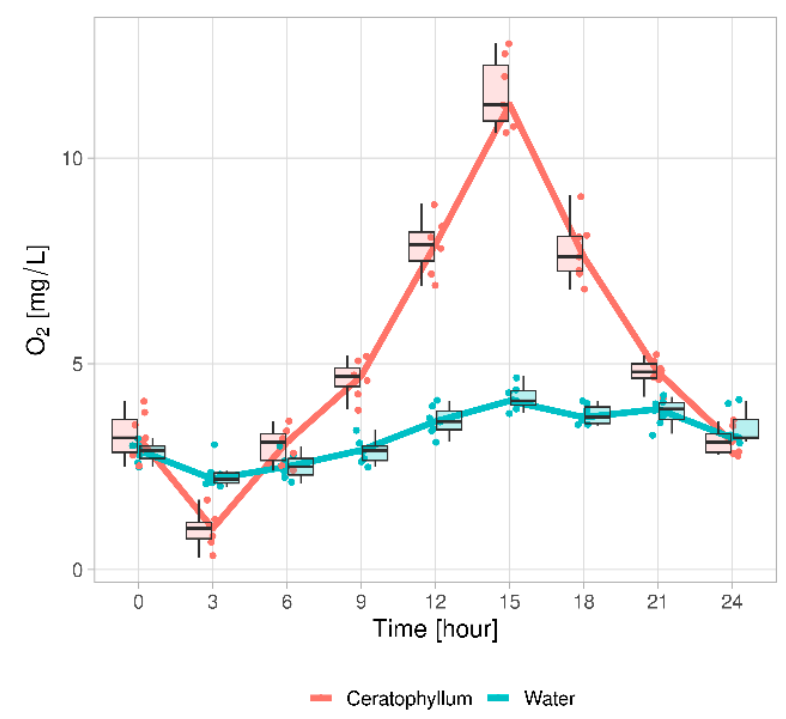

Figure 5. Daily changes in the oxygen content in the thickets of Ceratophyllum and in the epilimnion.

During the period of research in the lake, 209 taxa of ciliated protozoa (of them 183 identified to species) were observed (Table A1). Populations of many species are distributed within the range of several habitats identified, under the conditions of different oxygen contents. The presence of part of the population in the neighboring habitats, as a rule, with a lower density than in the optimum 
zone, indicated a range of tolerance of the species with respect to oxygen. The effect of oxygen on the functioning of ciliates and their spatial distribution is a known fact [24]. There are experimental data on the oxygen optima of a number of species of ciliates [46,47]. In our long-term field studies in different seasons, we observed maximum population densities of these species at the same values of oxygen contents. Such a coincidence of experimental and field data on the relationship between the densities of species populations and the concentration of oxygen in water allowed us to simplify reality and recognize that oxygen concentration is crucial, although, of course by no means the only factor in the ecological niche of ciliated species.

An analysis of principal components (PCA) was performed to determine how locations with different oxygen contents are grouped based on the abundances of 154 species of ciliates present in them. (In PCA analysis species occurring only sporadically were excluded.) During the research, 135 samples taken in all habitats were grouped by the oxygen concentrations rounded to integers. As a result, 15 locations with oxygen concentrations from 0 to 19 were obtained (Figure 6). The abundances of 154 species of ciliates found in our studies were averaged over these locations. Four groups can be seen in the plane of the first two principal components: (1) Oxygen-free conditions $(0 \mathrm{mg} / \mathrm{L})$, (2) locations with a high oxygen content (10-19 mg/L), (3) a group with a fairly narrow concentration range from 3 to $5 \mathrm{mg} / \mathrm{L}$, and (4) locations in which the oxygen concentration is in the ranges of 1-2 and 6-8 mg/L (Figure 6).

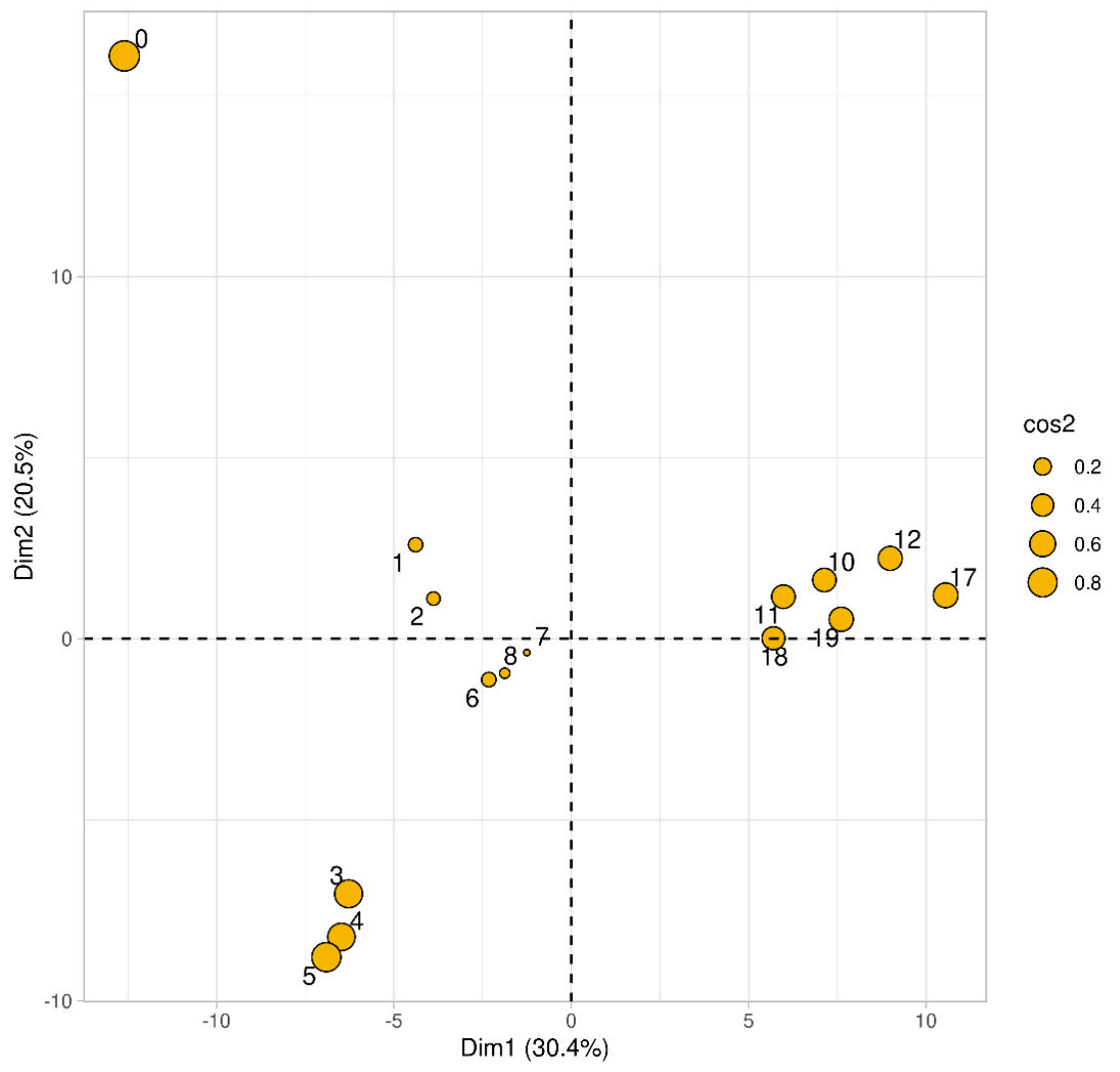

Figure 6. Principal component analysis (PCA) of locations with different oxygen contents based on the species abundances of the ciliates observed under these conditions. The numbers from 0 to 19 correspond to the rounded oxygen concentrations in $\mathrm{mg} / \mathrm{L}$. The area of the points is proportional to the quality of their representation on the plane of the first two principal components.

In order to verify our conclusions about the presence of four groups of locations by the oxygen content, the results of fuzzy clustering with a given number of clusters of 4 were superimposed on the 
PCA plane (Figure 7). It can be seen that the results of fuzzy clustering are in good agreement with the results obtained by means of the PCA method.

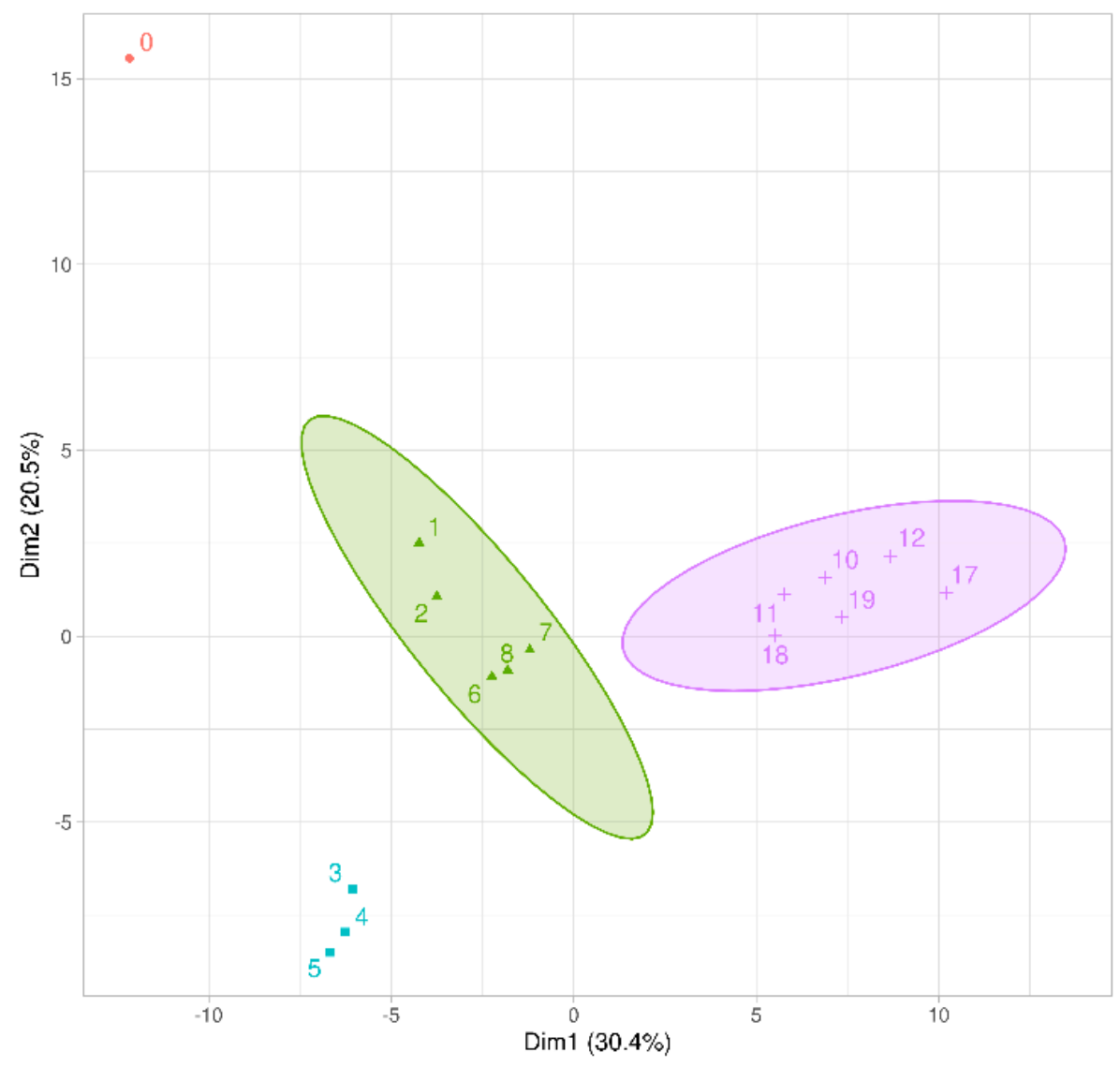

Figure 7. Fuzzy clustering superimposed on the plain of the first two principal components. The numbers from 0 to 19 correspond to rounded oxygen concentrations in $\mathrm{mg} / \mathrm{L}$.

The results of hierarchical clustering performed with the Ward method, pertaining to the locations ordered by depth and proximity of plants, are presented in Figure 8. Here, four clusters that correspond well to the groups isolated on the basis of oxygen concentration can also be seen. This is logical, since the concentration of oxygen in the investigated lake naturally varies with depth and in the vicinity of plants. Conditions in metaphytal—in the water between plants-are characterized by large daily fluctuations in oxygen contents. Moreover, this zone is practically devoid of ciliates. Single species from the decaying parts of plants found in this zone predetermined the affinity with the microaerophilic zone. Statistically, this position of the metaphyton is justified, but does not have a real biological meaning. The metaphytal can be considered as a dead or transit zone in which you can meet solitary species from adjacent assemblages. Most often, floating microoxyphilic species were recorded here.

On the basis of the analysis of the occurrence of 154 ciliates species in an oxygen gradient, four assemblages were identified: Microoxyphilic, oxyphilic, euryoxyphilic, and anoxyphilic [48]. The microoxyphilic assemblage includes the species that display preferences for the conditions with a stably low oxygen content. The upper limit of the tolerance range of the microoxyphilic species is usually limited to $3 \mathrm{mg}$ of oxygen per liter, but they reach a maximum concentration in an environment with an oxygen content below $2 \mathrm{mg} / \mathrm{L}$ (Figure 9a). Such conditions existed in the water column at a depth of 1.5-4 $\mathrm{m}$ from the end of spring to the beginning of autumn homogenization, as well as in the littoral zone; constantly in the bottom sediments, and on the surfaces of decaying dead parts of plants. The oxyphilic assemblage includes species that reach the largest abundances under the conditions of relatively high $(5-7 \mathrm{mg} / \mathrm{L})$ and stable oxygen content, and the amplitude of diurnal 
variations is small (1-2 mg/L). Distribution of abundances of the oxyphilic species is shown in Figure $9 \mathrm{~b}$. The euryoxyphilic assemblage includes species living at the plants where the oxygen concentration can vary in a very wide range: From 0 to $15 \mathrm{mg} / \mathrm{L}$, periodically reaching extremely high values-up to $300 \%$ of saturation (Figure 9c). The presence of many species exclusively on plants is determined by their tolerance to high oxygen content. The anoxyphilic assemblage unites species of habitats with anoxic conditions. Among anoxyphilic species, some species demonstrate endurance to the oxygen content in the environment (Figure 9d).

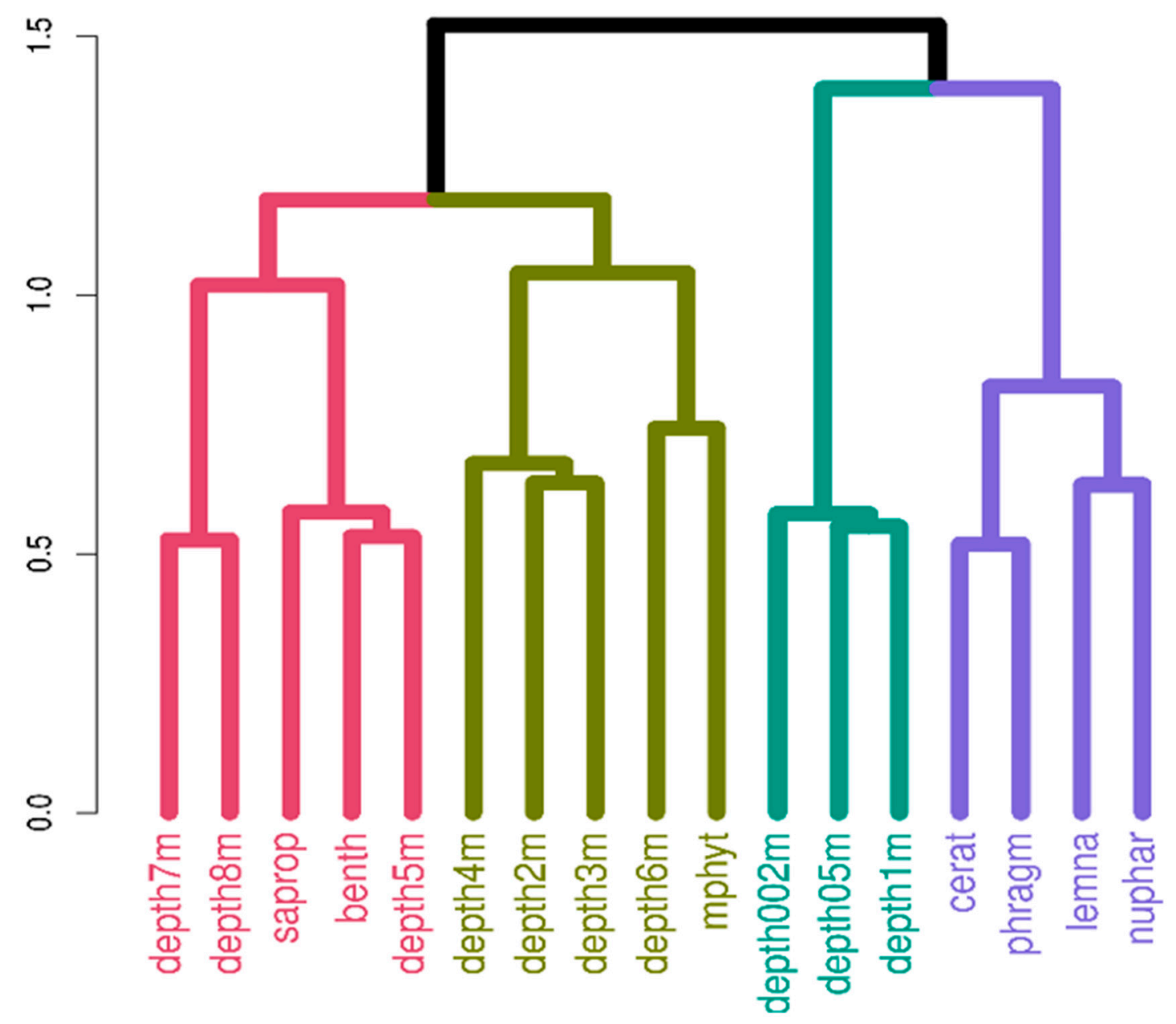

Figure 8. Ward's clustering of locations by depth and proximity of plants. Designation of habitats: benth-benthal in littoral, saprop-sapropel, depth 0.02, 0.5, 1-8 m-water column at depths of 0.02, 0.5, from 1 to $8 \mathrm{~m}$, mphyt-metaphytal, cerat-Ceratophyllum, phragm-Phragmites, lemna-Lemna and Spirodela, nuphar-Nuphar. 

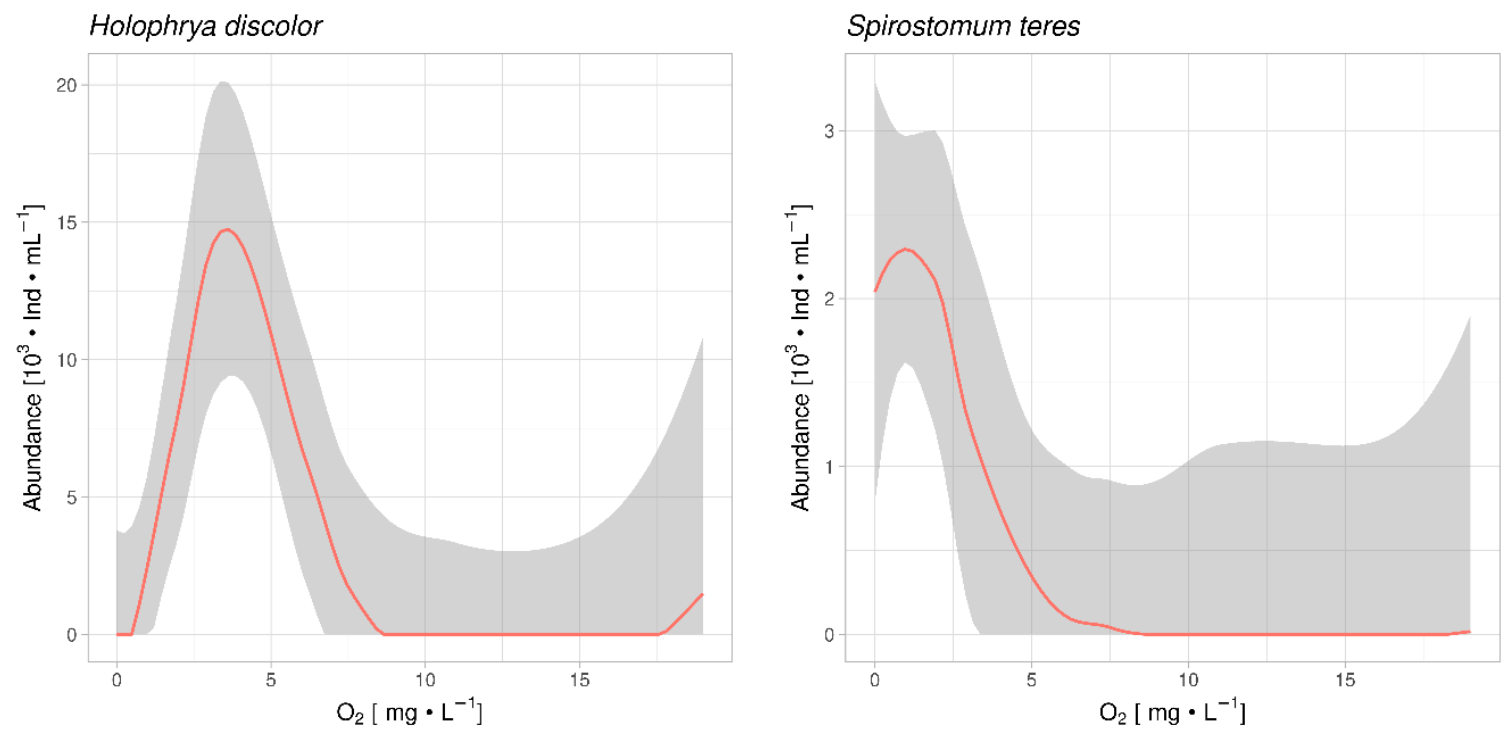

(a)
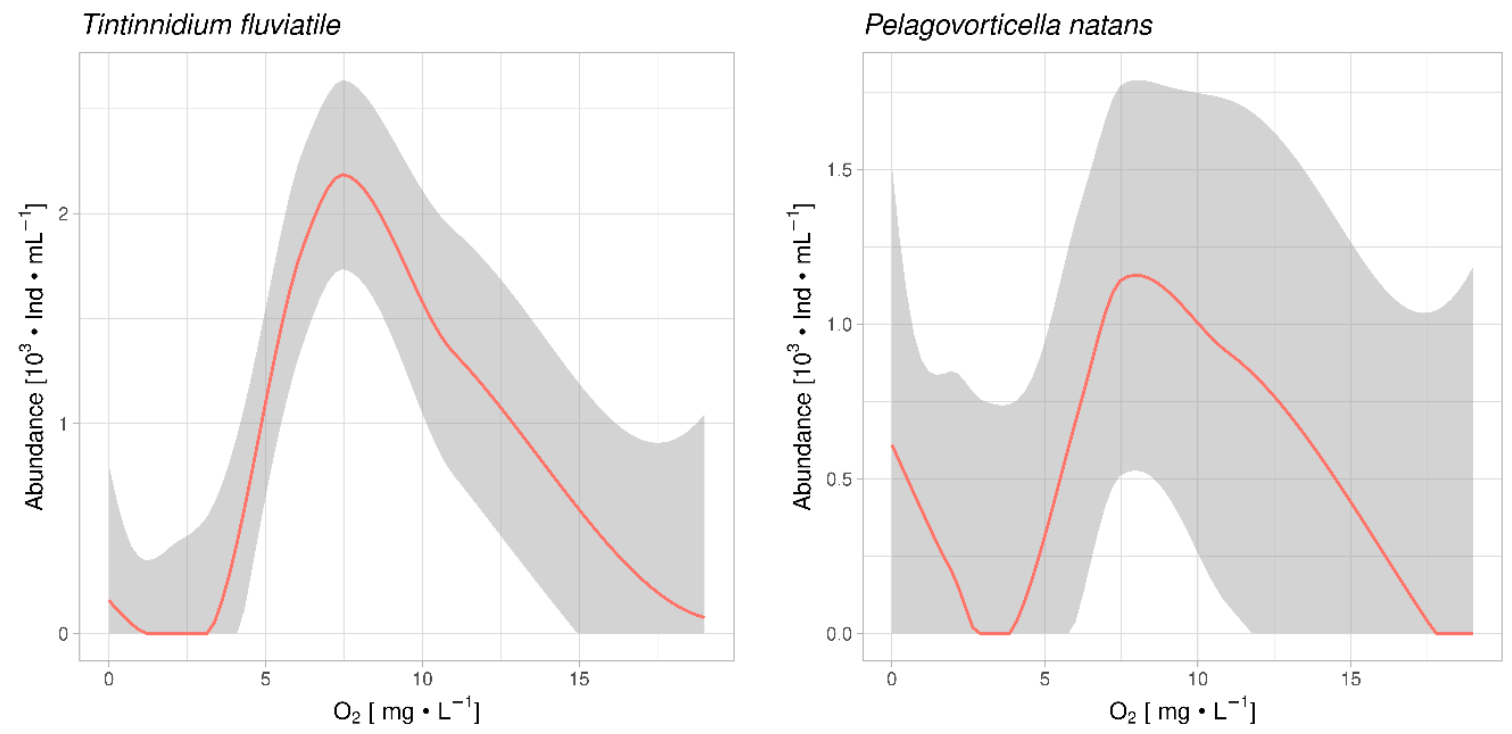

(b)

Figure 9. Cont. 

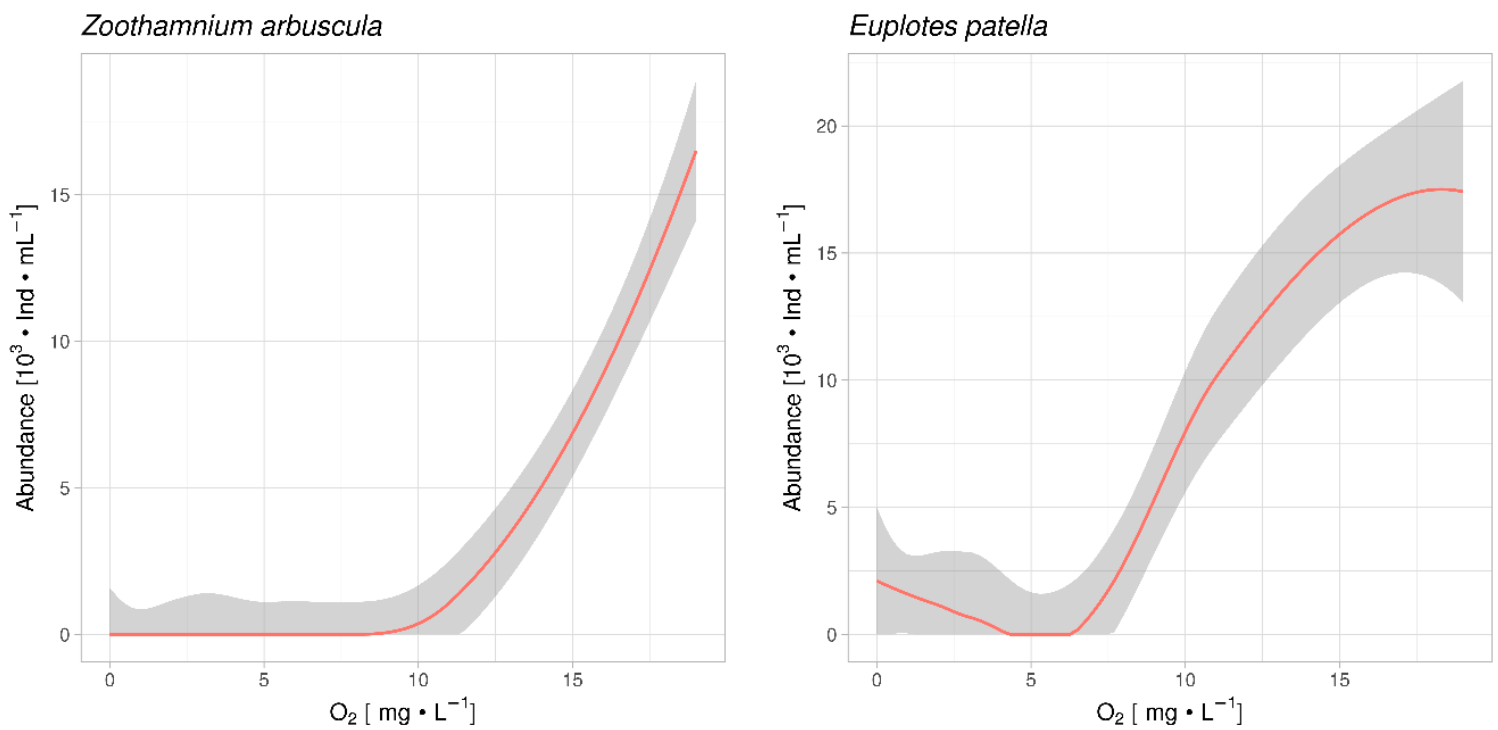

(c)
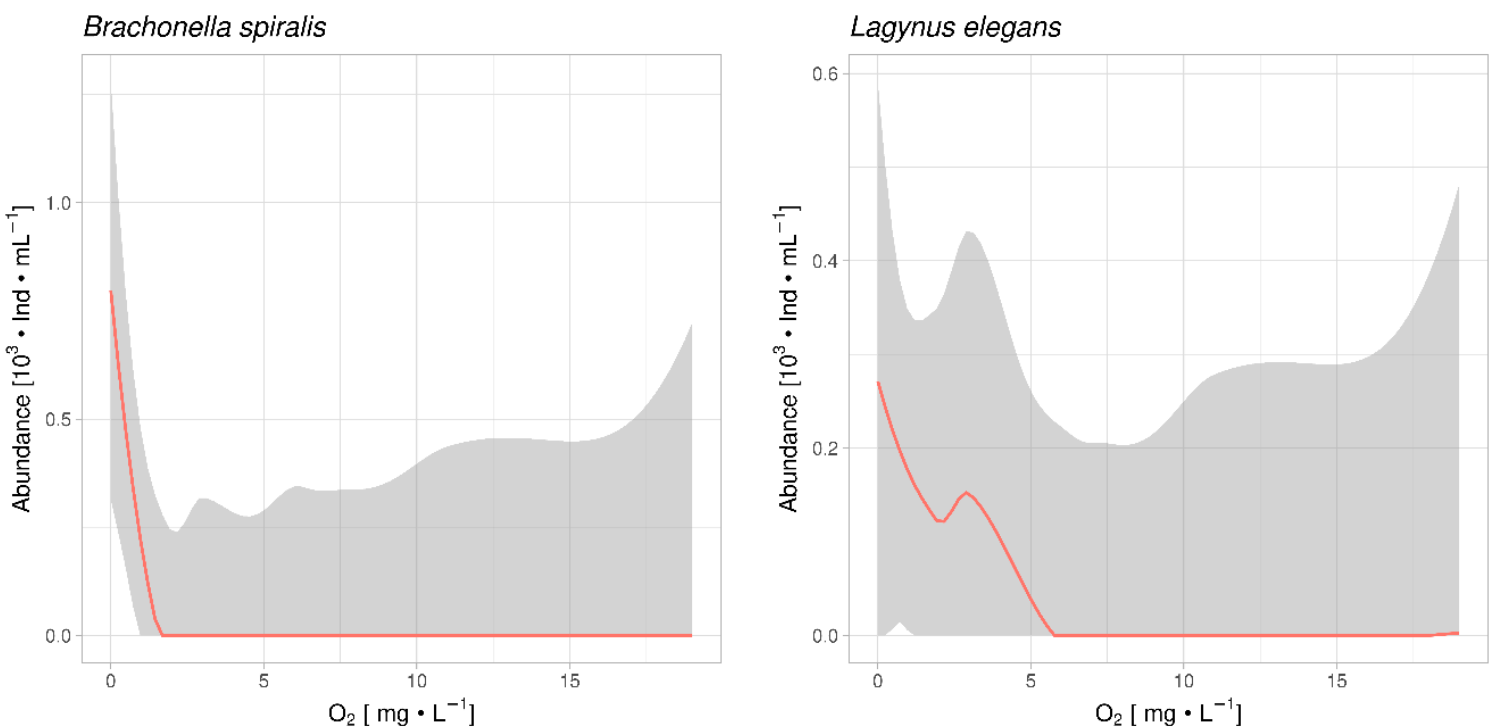

(d)

Figure 9. Distribution of the abundances of the species in the oxygen gradient: (a) Microoxyphilic species-Holophrya discolor and Spirostomum teres; (b) oxyphilic species-Tintinnidium fluviatile and Pelagovorticella natans; (c) euryoxyphilic species-Zoothamnium arbuscula and Euplotes patella; (d) anoxyphilic species-Brachonella spiralis and Lagynus elegans.

\section{Discussion}

\subsection{Assemblages Structure Analysis}

Clarification of the patterns of formation and functioning of biological diversity at the community level is one of the fundamental problems of biology and hydrobiology. The difficulties associated with the identification of local communities have been reported by many researchers $[49,50]$. The localization of the ciliate assemblages is usually based on the a priori division of the water body into biotopes: Benthal, pelagial, and periphytal. Further, on the basis of this classification, the organisms found 
within these a priori identified spatial boundaries are automatically assigned to the corresponding community: Benthic, periphytic, or pelagic [51,52].

The specialists working on a scale of one biotope developed the idea of its structure [52-54]. The consequences of this are the difficulties in distinguishing communities, in particular, the presence of the same species in the different communities. Thus, the researchers of plankton register the regular presence of the species that are considered to be benthic in the pelagic zone [51,52]. Conversely, the researchers of benthos note the planktonic species in the bottom sediments, for example, T. fluviatile, T. cylindrata, S. humile, S. minimum, S. vernalis, and some species of the Urotrichidae [55]. Significant difficulties are associated with the separation of the periphyton and benthic communities. The ciliates living in mountain rivers with a rocky bottom can equally be attributed to both benthos and periphyton, which shows the conventionality of dividing the fauna of such streams into the mentioned ecological groups [56].

There is an approach to the classification of communities based on the dominant species or on a group of co-occurring abundant species [33]. On the basis of this approach, the authors give an approximate species composition of several communities identified on the basis of the species co-occurring under conditions with different levels of organic pollution, in the pelagic zone, in swamps, and in capillary water of the soil [57]. For example, the Metopetum community is named after a group of indicator species from the genus Metopus. Most members of this community are anaerobic. Foissner and Berger [33] named a number of communities after the dominant species, for example, the Colpidietum community with the indicator species Colpidium colpoda, Trithigmostometum with the indicator species Trithigmostoma cucullulus, Carchesietosum with the indicator species Carchesium polypinum, and the Stentoretum community with indicator genus Stentor. They also distinguished the pelagic community: Oligotrichetea. However, the authors themselves noted that, for example, the euplanktonic species are common in most of those groups [33]. It was also proposed to distinguish the communities by their relation to environmental factors, while remaining within the framework of the biotopic approach paradigm and recognizing the existence of the "euplanktonic" species. The attempts to describe the spatial structure of the assemblages of ciliates in the body of water as a whole, rather than within a single biotope, have been made earlier, but the interpretation of the results remained within the boundaries of the biotopic paradigm $[5,9,27,58]$.

Since there are no physical obstacles that would prevent the population from spreading over the entire volume of water, the authors argue that the entire volume of the lake is a potential biotope for each species. But, despite the absence of physical barriers to the spread of species, their populations were concentrated mainly in places with oxygen conditions that meet their physiological needs. Oxygen is the most important factor determining the spatial distribution of protozoa [25]. The reasons for this dependence lie in the presence of a connection between the oxygen content and the food objects of protozoa, the needs of their symbionts, and, most importantly, the oxygen toxicity for some of them [24].

Therefore, at least three assemblages represented the pelagic zone: Anoxyphilic (in hypolimnion), microoxyphilic (in metalimnion), and oxyphilic, represented by the species traditionally attributed to plankton. However, the oxyphilic assemblage itself was restricted to the zone from the surface to a depth of 1.5-2 m. Microoxyphils predominated in the metalimnion, whereas the anoxyphilic species were almost exclusively present in the water column from a depth of four meters.

The microxyphilic group existed in the oxycline zone from late spring to the beginning of autumn homogenization. At the same time, the microoxyphilic assemblage also occupied the bottom sediments in the littoral. The same composition of species was recorded on the dead parts of plants, where the processes of decay took place, and the oxygen content did not exceed $3 \mathrm{mg} / \mathrm{L}$. Thus, the microoxyphilic assemblage was present simultaneously in three classical biotopes: Pelagial, periphytal, and benthal.

This illustrates the Ricklefs' claim that when solving the problem of local species diversity, we either ask the wrong questions or the right questions but on the wrong scale. In his opinion, a new understanding of the ecology of communities will come in the study of factors that affect 
the distribution of species in the whole space, in accordance with the gradients of environmental conditions [49]. This is also confirmed by our data obtained during the freezing period, when the amount of oxygen in the surface layer was below $1 \mathrm{mg} / \mathrm{L}$, and the entire volume of the lake was practically oxygen-free. During this period, the anoxyphilic species prevailed from the bottom to the surface. Obviously, the pelagic zone was occupied by a single assemblage: Anoxyphilic. A small amount of anoxia-resistant microoxyphils was found in vegetation and in the surface water layer due to the local presence of a small amount of oxygen $(1-2 \mathrm{mg} / \mathrm{L})$ caused by photosynthesis and artificial holes in the ice sheet.

There are also two assemblages in the periphytal, which contradicts its status as a single biotope. Thus, on dying plants and inanimate objects, where bacteria are actively developing, only the species from the microoxyphilic assemblage are present. Hence, on the subjects immersed to a depth of only $0.5 \mathrm{~m}$, we recorded the species living usually at a depth of three meters in the littoral. Periphytal on dying plants, as well as surfaces raised above the bottom, such as stones, sticks, and piles, is in every sense a continuation of the bottom. On these surfaces, due to the accumulation of sediments, the bacteria developing there provide stable microoxyphilic conditions. Most of the species found on the surface of vegetating plants are adapted to high oxygen content and, at the same time, to its significant fluctuations, which allows us to consider them as euryoxyphils. Such conditions are realized exclusively on the surfaces of vegetating plants. On vegetating plants, the composition of ciliates is predictable and excludes the presence of microoxyphils living on the rotting plant debris and on the bottom. These two groups can be slightly separated spatially, for example, occupying different tiers of one shoot of the hornwort, in which the lower dying parts are inhabited by microoxyphils, and the upper, actively vegetating, by euryoxyphils.

In view of the foregoing, in the absence of the information on the spatial distribution of oxygen, the samples taken at the boundary of two assemblages localized in the same biotope can pose significant problems for interpretation, giving grounds for erroneous conclusions about the unpredictable distribution of protozoa.

In undisturbed water bodies, the oxygen gradients in many respects coincide with visually distinct biotopes, which gave reason to consider the latter as habitats of communities. At present, when the water quality deteriorates due to the pollution of water bodies, a decrease in the diversity of protozoa is observed, largely due to the disappearance of suitable oxygen conditions for the oxyphilic and euryoxyphilic assemblages.

Summing up, it can be argued that protozoa are quite strictly determined in the space of water bodies by the oxygen gradients, rather than by according to common biotopes.

\subsection{Population Characteristics}

The formation of groups or assemblages is based on the similarity of the species requirements to the environmental conditions. Obviously, each species at the same time exists in its own niche to which it is adapted. Our results provide information on two important parameters of the ecological niche: The oxygen optimum and the range of the ecological tolerance of the species in the oxygen gradient. The species belonging to a particular assemblage can occur in a wide range of oxygen concentrations, but their optima mostly fit into a rather narrow range. Those optima are determined by the maximum population density in the space of the reservoir along the oxygen gradient. Within one assemblage, various types of distribution of populations in the oxygen gradient are observed.

For example, for Holophrya discolor, attributed by us to microoxyphils, various authors report a very wide range of oxygen concentrations at which this species was encountered. According to Bereczky [59], this species was found at the oxygen concentration of $10.2 \mathrm{mg} / \mathrm{L}$. According to Detcheva $[60,61]$, for this species the interval was between 3.0 and $9.3 \mathrm{mg} / \mathrm{L}$. Patrick et al. [62] indicated an interval of 7.0 to $9.0 \mathrm{mg} / \mathrm{L}$. The interval between 2.8 and $11.2 \mathrm{mg} / \mathrm{L}$ was pointed out by Foissner et al. [63]. The data presented give an idea of the range of tolerance of this species to oxygen, but do not allow judging which conditions are preferred or optimal for the species. According to our data, the concentration 
close to $3 \pm 0.5 \mathrm{mg} / \mathrm{L}$ can be considered optimal for this species. The lower limit of tolerance of this species is $0.5 \mathrm{mg} / \mathrm{L}$.

For microoxyphil Spirostomum teres, various authors mentioned the following oxygen concentrations at which it was found: $0.6-11 \mathrm{mg} / \mathrm{L} \mathrm{[64],} \mathrm{from} 0$ to $11 \mathrm{mg} / \mathrm{L}$ [65], 8.9-22 [59], 2.9-10.4 [61,66], 2.3-3.9 [67], and 0-7.2 [68,69]. In general, a very wide amplitude is indicated for this species-from 0 to $22 \mathrm{mg} / \mathrm{L}$. On the basis of our observations of its occurrence in the oxygen gradient, this species is tolerant to the anoxic conditions, and its optimum is in the range of $1-2 \mathrm{mg} / \mathrm{L} \mathrm{O}$.

The representatives of the oxyphilic assemblage are the species, most of which belong to the plankton ecological group. The data obtained on the tolerance ranges and optima of the representatives of this assemblage were illustrated on the example of the frequently occurring species. A typical representative of lake plankton and, according to our classification, the oxyphilic assembly, is Tintinnidium fluviatile. A number of authors noted that this species also occurs at fairly low values of dissolved oxygen. Reck [69] indicated a range from 0.6 to $15.9 \mathrm{mg} / \mathrm{L}$, other authors considered the oxygen concentrations above $4 \mathrm{mg} / \mathrm{L}$ as a lower limit: 9-14 mg/L [59], 4.7-6.5 mg/L [70]. Reck [69] indicated that a maximum population density of 500 ind/L was observed in the oxygen range $1.2-10.7 \mathrm{mg} / \mathrm{L}$. According to our data, the population of Tintinnidium fluviatile in the lake reached a density of $500 \mathrm{ind} / \mathrm{L}$ with the oxygen concentrations of $4 \mathrm{mg} / \mathrm{L}$ (below the optimum) and $15 \mathrm{mg} / \mathrm{L}$ (above the optimum), and under optimal conditions, in the range of $7-8 \mathrm{mg} / \mathrm{L}$, the density increased to $2000 \mathrm{ind} / \mathrm{L}$.

Another planktonic species from the oxyphilic group is Pelagovorticella natans. The species is usual for standing and low-flowing bodies of water. There is little information about its oxygen priorities. According to Sládeček and Sládecková [71], the species was found at the oxygen concentration of $11.6 \mathrm{mg} / \mathrm{L}$. According to our observations, Pelagovorticella natans has a fairly wide range of tolerance to the oxygen content and is able to withstand its fairly low concentrations. The species was noted during the blooming of water. A wide range of tolerance allows the species to be retained during the blooming periods, when the decrease in oxygen at night is sharp. In this case, the optimum for the species is in the range: $7-8 \mathrm{mg} / \mathrm{L}$.

A rather specific group, euryoxyphils, is represented mainly by the attached and crawling forms. As an example of attached euryoxyphils, we note Zoothamnium arbuscula. This species is rarely encountered today due to the pollution of water bodies. According to our studies, the species is found exclusively under the conditions of high oxygen concentrations: From $10 \mathrm{mg} / \mathrm{L}$ and higher, which is consistent with data of other authors. Schönborn [72] found this species under oxygen concentrations of $8-10 \mathrm{mg} / \mathrm{L}$. The population density of this species increased along with the oxygen content (the graphs in Figure $9 \mathrm{c}$ show the oxygen concentrations in daylight).

A similar reaction to an increase in the oxygen content was demonstrated by the crawling representative of the euryoxyphilic assemblage-Euplotes patella. According to the published data, the species was found at oxygen concentrations of 7-9 mg/L [62], 0-12 mg/L [73], and 0.4-12 [60,61,66,74-77], 4.7-11.3 [78], 3.5-10.9 [63]. All authors indicate that the upper limit of the oxygen content for the species is above $10 \mathrm{mg} / \mathrm{L}$. At the same time, the its lower limit of $0 \mathrm{mg} / \mathrm{L}$ confirms our assertion that the species of this group are the species that are adapted to exist in a wide range of fluctuations of this factor and are able to survive anoxia as well as high oxygen concentrations, which are avoided by representatives of other assemblies. According to our data, Euplotes patella reached the maximum population densities under the oxygen content above $15 \mathrm{mg} / \mathrm{L}$.

The anoxyphilic assemblage in the lake was quite diverse, and its distribution was limited mainly by the sapropel-filled profundal, where the oxygen-free conditions were maintained all the time, and by hypolimnion during the periods of summer and winter stagnation. Most species of the anoxyphilic group were not observed even under the conditions of minimal oxygen concentrations. Some representatives of the anoxyphilic assemblage showed oxygen tolerance. These include the omnivore Lagynus elegans. According to the published data, this species occurred at the concentrations of $\mathrm{O}_{2}$ up to $6 \mathrm{mg} / \mathrm{L}$. Our studies have confirmed such an amplitude of its tolerance. Nevertheless, 
based on the quantitative representation of Lagynus elegans, the optimum of this species was localized in the oxygen-free region, and with an increase in the oxygen content in the medium, the population density rapidly decreased.

\section{Conclusions}

A study on the distribution of the ciliate populations in the oxygen gradient, regardless of the differentiation of the space of the reservoir into the water column, bottom, and periphytal, enabled us to identify the structuring of the ciliate population in the volume of the reservoir. The oxyphilic assemblage of species exists under conditions with a stably high oxygen content, which are maintained for most of the year in the epilimnion. It consists of species whose oxygen optima are about 5-7 mg/L. The microoxyphilic assemblage of species exists under the conditions with a consistently low oxygen content. These conditions are stably preserved on the surface of the bottom sediments in the littoral and are periodically formed in the metalimnion, as well as on the surface of decaying macrophytes. The oxygen optimum for it is about $2 \mathrm{mg} / \mathrm{L}$. The euryoxyphilic assemblage is formed under conditions with a large amplitude of diurnal oxygen variations. The euryoxyphilic assemblage consists of species that are tolerant of both extremely high and low oxygen concentrations. The maximum oxygen concentrations are formed on the surface of photosynthetic macrophytes. Anoxyphilic assemblage is formed under conditions of a stable anoxia-in the profundal zone and, periodically, in the hypolimnion. The species composition of these assemblages is predictable and relatively stable.

Changing the configuration of the distribution of zones with relatively stable oxygen conditions leads to a change in the spatial localization of assemblages. The diversity of the ciliated protozoa in water bodies also depends on the stability and diversity of the oxygen gradients.

Author Contributions: Conceptualization, R.B.; methodology, R.B. and T.K.; software, Y.D. and R.B.; validation, R.B.; formal analysis, R.B.; investigation, R.B. and T.K.; resources, R.B. and T.K.; data curation, R.B., T.K., J.S.-C., and G.Ł.; writing—original draft preparation, R.B., T.K., and Y.D.; writing—review and editing, R.B., T.K., and G.Ł.; visualization, R.B. and T.K.; supervision, R.B. All authors have read and agreed to the published version of the manuscript.

Funding: This research received no external funding.

Acknowledgments: The authors are much obliged to the two anonymous reviewers for very valuable comments.

Conflicts of Interest: The authors declare no conflict of interest. 


\section{Appendix A}

Table A1. Ciliate species found in the different sites in the floodplain lake (basin of the Vorskla River).

\begin{tabular}{|c|c|c|c|c|c|c|c|}
\hline \multirow{2}{*}{ Sites } & \multicolumn{3}{|c|}{ Pelagial } & \multicolumn{2}{|c|}{ Bottom } & \multirow{2}{*}{ Metaphytal } & \multirow{2}{*}{ Periphytal of Macrophytes ** } \\
\hline & & & & Littoral & Profundal & & \\
\hline Oxygen condition & oxy & microoxy & anoxy & microoxy & anoxy & euryoxy & euryoxy \\
\hline Acaryophrya sphaerica (Gelei, 1934) & $\mathrm{x}$ & & & & & & \\
\hline Acineria incurvata Dujardin, 1841 & & & & & & & $\mathrm{x}$ \\
\hline Actinobolina vorax (Wenrich, 1929) & $\mathrm{x}$ & & * & & & $\mathrm{x}$ & \\
\hline Amphileptus agilis Penard, 1922 & & & & & & & $\mathrm{x}$ \\
\hline Amphileptus pleurosigma (Stokes, 1884) & & & & $\mathrm{x}$ & & & $x$ \\
\hline Amphileptus procerus (Penard, 1922) & & & & & & & $\mathrm{x}$ \\
\hline Amphileptus sp. & & & & & & & $\mathrm{x}$ \\
\hline Anteholosticha monilata (Kahl, 1928) & & & & & & & $\mathrm{x}$ \\
\hline Apsiktrata gracilis (Penard, 1922) & & & $\mathrm{xx}$ & & $\mathrm{xx}$ & & \\
\hline Askenasia sp. & $\mathrm{x}$ & $\mathrm{x}$ & & & & & \\
\hline Askenasia volvox (Eichwald, 1852) & $\mathrm{xx}$ & $\mathrm{x}$ & & & & $\mathrm{x}$ & $\mathrm{x}$ \\
\hline Aspidisca cicada (Müller, 1786) & $\mathrm{x}$ & & & & $\mathrm{x}$ & & $\mathrm{xx}$ \\
\hline Aspidisca lynceus (Müller, 1773) & & & & $\mathrm{x}$ & $\mathrm{x}$ & & $\mathrm{xx}$ \\
\hline Astylozoon faurei (Kahl, 1935) & $\mathrm{x}$ & $\mathrm{x}$ & $*$ & $\mathrm{x}$ & & & \\
\hline Blepharisma sp. & $\mathrm{x}$ & & & & & & \\
\hline Bothrostoma sp. & & & $x x$ & & & & \\
\hline Bothrostoma undulans (Stokes, 1887) & & & $\mathrm{xx}$ & & & & * \\
\hline Brachonella campanula (Kahl, 1932) & & & & & $\mathrm{xx}$ & & $*$ \\
\hline Brachonella spiralis (Smith, 1897) & & & & $*$ & $\mathrm{xx}$ & & \\
\hline Bursellopsis gargamellae (Fauré-Fremiet, 1922) & $\mathrm{x}$ & $\mathrm{x}$ & & & & & \\
\hline Bursellopsis truncata (Kahl, 1927) & $x$ & & & & & & \\
\hline Caenomorpha medusula Perty, 1852 & & & $\mathrm{xx}$ & * & $\mathrm{xx}$ & & \\
\hline Caenomorpha uniserialis (Levander, 1894) & & & & $\mathrm{x}$ & & & \\
\hline
\end{tabular}


Table A1. Cont.

\begin{tabular}{|c|c|c|c|c|c|c|c|}
\hline \multirow{2}{*}{ Sites } & & \multirow{2}{*}{ Pelagial } & & \multicolumn{2}{|c|}{ Bottom } & \multirow{2}{*}{ Metaphytal } & \multirow{2}{*}{ Periphytal of Macrophytes ** } \\
\hline & & & & Littoral & Profundal & & \\
\hline Campanella umbellaria (Linnaeus, 1758) & & & & $\mathrm{x}$ & & $\mathrm{x}$ & $x x$ \\
\hline Carchesium polypinum (Linnaeus, 1758) & & & & & & & $\mathrm{xx}$ \\
\hline Caudiholosticha viridis (Kahl, 1932) & & $\mathrm{x}$ & $\mathrm{x}$ & & & & \\
\hline Chaenea sp. & & & & & & & $\mathrm{x}$ \\
\hline Chilodonella uncinata (Ehrenberg, 1838) & & & & $\mathrm{x}$ & & & $\mathrm{xx}$ \\
\hline Chilodontopsis depressa (Perty, 1852) & & & & & & & $\mathrm{x}$ \\
\hline Cinetochilum margaritaceum (Ehrenberg, 1831) & $x x$ & $\mathrm{x}$ & & $x$ & $x$ & $\mathrm{x}$ & $\mathrm{xx}$ \\
\hline Codonella cratera $($ Leidy, 1877$)$ & $\mathrm{x}$ & & & & & & \\
\hline Coleps amphacanthus (Ehrenberg, 1833) & $\mathrm{x}$ & $\mathrm{x}$ & $*$ & & & & $\mathrm{x}$ \\
\hline Coleps elongatus (Ehrenberg, 1830) & & $\mathrm{x}$ & $*$ & $\mathrm{x}$ & & & \\
\hline Coleps hirtus (Múller, 1786) & $\mathrm{xx}$ & $x x$ & $*$ & $\mathrm{xx}$ & $*$ & $\mathrm{x}$ & $x x$ \\
\hline Coleps nolandi (Kahl, 1930) & 1 & & & $\mathrm{x}$ & $*$ & $\mathrm{x}$ & $\mathrm{x}$ \\
\hline Colpidium colpoda (Losana, 1829) & & & & & & & $\mathrm{x}$ \\
\hline Cristigera media (Kahl, 1928) & & & & $\mathrm{x}$ & & & \\
\hline Cristigera phoenix (Penard, 1922) & & & $\mathrm{x}$ & & $\mathrm{x}$ & & \\
\hline Cristigera setosa (Kahl, 1928) & & $\mathrm{x}$ & & $\mathrm{x}$ & $\mathrm{xx}$ & & $\mathrm{x}$ \\
\hline Ctedoctema acanthocryptum (Stokes, 1884) & $\mathrm{x}$ & $\mathrm{x}$ & & $\mathrm{x}$ & & & $x x$ \\
\hline Cyclidium glaucoma (Müller, 1773) & $\mathrm{x}$ & $\mathrm{x}$ & & $\mathrm{x}$ & & & $\mathrm{x}$ \\
\hline Cyclotrichium gigas (Fauré-Fremiet, 1924) & & $\mathrm{x}$ & & & & $\mathrm{x}$ & \\
\hline Cyclotrichium sp. & $\mathrm{x}$ & $\mathrm{x}$ & & & & & \\
\hline Cyclotrichium viride (Gajewskaja, 1933) & $\mathrm{x}$ & & & & & & \\
\hline Dexiostoma campylum (Stokes, 1886) & & & & & & & $\mathrm{x}$ \\
\hline Dexiotricha granulosa (Kent, 1881) & & $\mathrm{xx}$ & $\mathrm{xx}$ & $\mathrm{x}$ & $\mathrm{xx}$ & & $\mathrm{x}$ \\
\hline Disematostoma bütschlii (Lauterborn, 1894) & $\mathrm{x}$ & $\mathrm{x}$ & & & $*$ & $\mathrm{x}$ & $\mathrm{x}$ \\
\hline Disematostoma tetraedricum (Fauré-Fremiet, 1924) & & & & & & & $\mathrm{x}$ \\
\hline Enchelyodon elegans (Kahl, 1926) & $x x$ & $\mathrm{x}$ & & $\mathrm{x}$ & & & $\mathrm{x}$ \\
\hline Enchelys pupa (Müller, 1786) & $\mathrm{x}$ & $x$ & & & & & $\mathrm{x}$ \\
\hline
\end{tabular}


Table A1. Cont.

\begin{tabular}{|c|c|c|c|c|c|c|c|}
\hline \multirow{2}{*}{ Sites } & & \multirow{2}{*}{ Pelagial } & & \multicolumn{2}{|c|}{ Bottom } & \multirow{2}{*}{ Metaphytal } & \multirow{2}{*}{ Periphytal of Macrophytes ** } \\
\hline & & & & Littoral & Profundal & & \\
\hline Enchelys sp. & & & & & & & $\mathrm{x}$ \\
\hline Epalxella bidens (Kahl, 1932) & & & & & $\mathrm{x}$ & & \\
\hline Epalxella mirabilis (Roux, 1899) & & & $\mathrm{x}$ & $\mathrm{x}$ & $\mathrm{xx}$ & & \\
\hline Epalxella sp. & & & & & $\mathrm{x}$ & & \\
\hline Epistylis plicatilis (Ehrenberg, 1831) & & & & & & & $\mathrm{x}$ \\
\hline Epistylis procumbens (Zacharias, 1897) & $\mathrm{x}$ & & & & & & \\
\hline Euplotes patella (Müller, 1773) & & $\mathrm{x}$ & $\mathrm{xx}$ & $\mathrm{xx}$ & $\mathrm{x}$ & $\mathrm{x}$ & $\mathrm{xx}$ \\
\hline Euplotopsis affinis (Dujardin, 1841) & & & & & & $\mathrm{x}$ & $\mathrm{xx}$ \\
\hline Frontonia acuminata (Ehrenberg, 1834) & & $\mathrm{x}$ & & $\mathrm{x}$ & & & $\mathrm{x}$ \\
\hline Frontonia leucas (Ehrenberg, 1834) & & $\mathrm{x}$ & & $\mathrm{x}$ & & & \\
\hline Frontoniella complanata (Wetzel, 1927) & & & & $\mathrm{x}$ & & & $\mathrm{x}$ \\
\hline Gastronauta membranaceus (Bütschli, 1889) & & & & & & & $\mathrm{x}$ \\
\hline Glaucoma scintillans (Ehrenberg, 1830) & & $\mathrm{x}$ & & $\mathrm{x}$ & & & $\mathrm{x}$ \\
\hline Halteria bifurcata (Tamar, 1968) & & & & $\mathrm{x}$ & & & \\
\hline Halteria grandinella (Müller, 1773) & $x x$ & $x x$ & & $\mathrm{x}$ & * & $\mathrm{x}$ & $\mathrm{xx}$ \\
\hline Halteria minuta (Tamar, 1968) & $\mathrm{xx}$ & $\mathrm{x}$ & * & & * & & $\mathrm{x}$ \\
\hline Histiobalantium natans (Claparède, Lachmann, 1858) & $\mathrm{x}$ & $\mathrm{xx}$ & $\mathrm{x}$ & $\mathrm{x}$ & $\mathrm{x}$ & & $\mathrm{x}$ \\
\hline Holophrya discolor (Ehrenberg, 1834) & & $\mathrm{x}$ & $\mathrm{x}$ & & $\mathrm{x}$ & & $\mathrm{x}$ \\
\hline Holophrya ovum (Ehrenberg, 1831) & $\mathrm{x}$ & $x x$ & $\mathrm{xx}$ & $\mathrm{xx}$ & $\mathrm{xx}$ & & $\mathrm{xx}$ \\
\hline Holophrya simplex (Schewiakoff, 1893) & & & & & & & $\mathrm{x}$ \\
\hline Holophrya sp. & & $\mathrm{x}$ & & & * & & $\mathrm{x}$ \\
\hline Holophrya teres (Ehrenberg, 1834) & & $\mathrm{x}$ & $\mathrm{x}$ & & $\mathrm{x}$ & & $\mathrm{x}$ \\
\hline Holosticha pullaster (Müller, 1773) & $\mathrm{x}$ & $\mathrm{x}$ & & $\mathrm{x}$ & & $\mathrm{x}$ & $\mathrm{xx}$ \\
\hline Holosticha sp. & & & $*$ & & & & $\mathrm{x}$ \\
\hline Kerona pediculus (Müller, 1773) & & & & & & & $\mathrm{x}$ \\
\hline Lacrymaria filiformis (Maskell, 1886) & & & & $\mathrm{x}$ & & & $\mathrm{x}$ \\
\hline Lacrymaria olor (Müller, 1786) & & & & & & & $\mathrm{x}$ \\
\hline
\end{tabular}


Table A1. Cont.

\begin{tabular}{|c|c|c|c|c|c|c|c|}
\hline \multirow{2}{*}{ Sites } & & \multirow{2}{*}{ Pelagial } & & \multicolumn{2}{|c|}{ Bottom } & \multirow{2}{*}{ Metaphytal } & \multirow{2}{*}{ Periphytal of Macrophytes ** } \\
\hline & & & & Littoral & Profundal & & \\
\hline Lacrymaria sp. & & & & & & & $\mathrm{x}$ \\
\hline Lagynus elegans (Engelmann, 1862) & & & $\mathrm{x}$ & & $\mathrm{xx}$ & & \\
\hline Lembadion bullinum (Müller, 1786) & & $\mathrm{x}$ & & & & & $\mathrm{x}$ \\
\hline Lembadion lucens (Maskell, 1887) & & & & & & & $\mathrm{x}$ \\
\hline Lembadion magnum (Stokes, 1887) & & $\mathrm{x}$ & & $\mathrm{x}$ & & & $\mathrm{x}$ \\
\hline Leptopharynx eurystomus (Kahl, 1931) & & & & & & & $x$ \\
\hline Limnostrombidium viride (Stein, 1867) & $\mathrm{xx}$ & $\mathrm{x}$ & & $\mathrm{x}$ & & $\mathrm{x}$ & $\mathrm{x}$ \\
\hline Linostomella vorticella (Ehrenberg, 1834) & $\mathrm{xx}$ & $\mathrm{x}$ & $\mathrm{x}$ & $\mathrm{x}$ & $\mathrm{x}$ & $\mathrm{x}$ & \\
\hline Litonotus armillatus (Penard, 1922) & $\mathrm{x}$ & & & & & $\mathrm{x}$ & $\mathrm{x}$ \\
\hline Litonotus fasciola (Ehrenberg, 1838) & & & & & & & $\mathrm{x}$ \\
\hline Litonotus fusidens (Kahl, 1926) & & & & & & & $\mathrm{x}$ \\
\hline Litonotus hirundo (Penard, 1922) & $\mathrm{x}$ & & & & $*$ & $\mathrm{x}$ & $\mathrm{x}$ \\
\hline Litonotus sp. & & & & & & & $\mathrm{x}$ \\
\hline Longifragma obliqua (Kahl, 1926) & $\mathrm{xx}$ & $\mathrm{x}$ & & & & $\mathrm{x}$ & $\mathrm{x}$ \\
\hline Loxocephalus lucidus (Smith, 1897) & & & & & & & $\mathrm{x}$ \\
\hline Loxocephalus luridus (Eberhard, 1862) & & $x x$ & $x x$ & $\mathrm{x}$ & $x x$ & & \\
\hline Loxodes magnus (Stokes, 1887) & & $\mathrm{xx}$ & $\mathrm{x}$ & $\mathrm{x}$ & $\mathrm{x}$ & & * \\
\hline Loxodes striatus (Engelmann, 1862) & & $\mathrm{x}$ & * & $\mathrm{x}$ & & & \\
\hline Loxophyllum meleagris (Müller, 1773) & & & & & & & $\mathrm{x}$ \\
\hline Loxophyllum sp. & & & & & & & $\mathrm{x}$ \\
\hline Mesodinium pulex (Claparède, Lachmann, 1859) & $\mathrm{x}$ & $\mathrm{x}$ & & & & & \\
\hline Metopus caudatus (Da Cunha, 1915) & & & & & $\mathrm{xx}$ & & \\
\hline Metopus es (Müller, 1776) & & & $\mathrm{x}$ & $\mathrm{x}$ & $\mathrm{x}$ & & \\
\hline Metopus hasei (Sondheim, 1929) & & & & & $\mathrm{x}$ & & \\
\hline Metopus setosus (Kahl, 1927) & & & & & $\mathrm{x}$ & & \\
\hline Metopus sp. & & & $\mathrm{x}$ & * & & & \\
\hline Metopus striatus (McMurrich, 1884) & & & & & $\mathrm{x}$ & & \\
\hline
\end{tabular}


Table A1. Cont.

\begin{tabular}{|c|c|c|c|c|c|c|c|}
\hline \multirow{2}{*}{ Sites } & & \multirow{2}{*}{ Pelagial } & & \multicolumn{2}{|c|}{ Bottom } & \multirow{2}{*}{ Metaphytal } & \multirow{2}{*}{ Periphytal of Macrophytes ** } \\
\hline & & & & Littoral & Profundal & & \\
\hline Microthorax pusillus (Engelmann, 1862) & & & & & & & $\mathrm{x}$ \\
\hline Microthorax tridentatus (Penard, 1922) & & & & & & & $\mathrm{x}$ \\
\hline Monochilum elongatum (Mermod, 1914) & & & & $\mathrm{x}$ & $*$ & & $\mathrm{x}$ \\
\hline Monodinium balbianii (Fabre-Domergue, 1888) & $\mathrm{xx}$ & $\mathrm{x}$ & ${ }^{*}$ & $\mathrm{x}$ & & $\mathrm{x}$ & $\mathrm{xx}$ \\
\hline Mylestoma sp. & & & & $\mathrm{x}$ & & & \\
\hline Obertrumia aurea (Ehrenberg, 1834) & & & & $\mathrm{x}$ & & & $\mathrm{x}$ \\
\hline Onychodromus grandis Stein, 1859 & & & & & & & $\mathrm{x}$ \\
\hline Opercularia nutans (Ehrenberg, 1831) & & & & & & & $\mathrm{xx}$ \\
\hline Ophrydium sessile (Kent, 1882) & & & & & & & $\mathrm{x}$ \\
\hline Ophryoglena macrostoma (Kahl, 1928) & & & & & & & $\mathrm{x}$ \\
\hline Ophryoglena maligna (Penard, 1922) & & & & & & & $\mathrm{x}$ \\
\hline Ophryoglena oblonga (Gajevskaja, 1927) & & & & & & & $\mathrm{x}$ \\
\hline Ophryoglena utriculariae (Kahl, 1931) & & & & & & & $\mathrm{x}$ \\
\hline Opisthodon niemeccensis (Stein, 1859) & & & & & $\mathrm{x}$ & & \\
\hline Oxytricha chlorelligera (Kahl, 1932) & & $\mathrm{x}$ & $\mathrm{x}$ & & $\mathrm{x}$ & & \\
\hline Oxytricha parvistyla (Stokes, 1887) & & & & & & & $\mathrm{x}$ \\
\hline Oxytricha setigera (Stokes, 1891) & & & & & & & $\mathrm{x}$ \\
\hline Oxytricha sp. & & & & & & $\mathrm{x}$ & $\mathrm{x}$ \\
\hline Paradileptus elephantinus (Svec, 1897) & $\mathrm{x}$ & & & & & & \\
\hline Paradileptus sp. & & & & & & & $\mathrm{x}$ \\
\hline Paramecium bursaria (Ehrenberg, 1831) & & $\mathrm{x}$ & & & & & $\mathrm{xx}$ \\
\hline Paramecium caudatum (Ehrenberg, 1833) & & & & $\mathrm{x}$ & & & $\mathrm{x}$ \\
\hline Paramecium putrinum (Claparède, Lachmann, 1859) & & & & $\mathrm{x}$ & & & $\mathrm{x}$ \\
\hline Paraurostyla weissei (Stein, 1859) & & $\mathrm{x}$ & & & & & $\mathrm{x}$ \\
\hline Paraurotricha discolor (Kahl, 1930) & $\mathrm{x}$ & $\mathrm{x}$ & & $\mathrm{x}$ & $\mathrm{x}$ & $\mathrm{x}$ & $\mathrm{xx}$ \\
\hline Pelagohalteria cirrifera (Kahl, 1932) & & $\mathrm{x}$ & $\mathrm{x}$ & & & $\mathrm{x}$ & $\mathrm{x}$ \\
\hline Pelagostrombidium mirabile (Penard, 1916) & $\mathrm{x}$ & & & & & & \\
\hline
\end{tabular}


Table A1. Cont.

\begin{tabular}{|c|c|c|c|c|c|c|c|}
\hline \multirow{2}{*}{ Sites } & \multicolumn{3}{|c|}{ Pelagial } & \multicolumn{2}{|c|}{ Bottom } & \multirow{2}{*}{ Metaphytal } & \multirow{2}{*}{ Periphytal of Macrophytes ** } \\
\hline & & & & Littoral & Profundal & & \\
\hline Pelagovorticella mayeri (Fauré-Fremiet, 1923) & $\mathrm{x}$ & $\mathrm{x}$ & & & & $\mathrm{x}$ & \\
\hline Pelagovorticella natans (Fauré-Fremiet, 1924) & $\mathrm{x}$ & $\mathrm{x}$ & & & & & \\
\hline Pelodinium reniforme (Lauterborn, 1908) & & & & * & & & \\
\hline Phascolodon vorticella (Stein, 1859) & $\mathrm{x}$ & & & & & & \\
\hline Phialina coronata (Claparède \& Lachmann, 1859) & & & & & & & $\mathrm{x}$ \\
\hline Phialina pupula (Müller, 1773) & & $\mathrm{x}$ & & & $\mathrm{x}$ & & \\
\hline Phialina sp. & & & & & & & $x$ \\
\hline Phialina vertens (Stokes, 1885) & & & & $\mathrm{x}$ & & & $\mathrm{x}$ \\
\hline Plagiocampa rouxi (Kahl, 1926) & & & & $\mathrm{x}$ & & & \\
\hline Plagiopyla nasuta (Stein, 1860) & & $\mathrm{x}$ & $\mathrm{x}$ & & $\mathrm{xx}$ & & \\
\hline Pleuronema coronatum (Kent, 1881) & & $\mathrm{x}$ & & $\mathrm{x}$ & $\mathrm{x}$ & $\mathrm{x}$ & $\mathrm{x}$ \\
\hline Podophrya fixa (Müller, 1786) & & & & & & & $\mathrm{x}$ \\
\hline Prorodon niveus (Ehrenberg, 1834) & & & & & & & $\mathrm{x}$ \\
\hline Protocyclidium citrullus (Cohn, 1866) & & & & $\mathrm{x}$ & $\mathrm{x}$ & & $\mathrm{x}$ \\
\hline Pseudochilodonopsis piscatoris (Blochmann, 1895) & & & & $\mathrm{x}$ & & $\mathrm{x}$ & \\
\hline Pseudocohnilembus pusillus (Quennerstedt, 1869) & $\mathrm{xx}$ & $\mathrm{xx}$ & & $\mathrm{x}$ & & $x$ & $\mathrm{xx}$ \\
\hline Pseudohaplocaulus anabaenae (Stiller, 1940) & $\mathrm{x}$ & & & & & & \\
\hline Pseudomicrothorax agilis (Mermod, 1914) & & & & & & & $\mathrm{x}$ \\
\hline Pseudomonilicaryon anser (Müller, 1773) & & & & & & & $\mathrm{x}$ \\
\hline Rhagadostoma completum (Kahl, 1926) & & $\mathrm{x}$ & $*$ & $\mathrm{x}$ & & & $\mathrm{x}$ \\
\hline Rimostrombidium humile (Penard, 1922) & $\mathrm{xx}$ & $\mathrm{x}$ & & & & $\mathrm{x}$ & \\
\hline Rimostrombidium velox (Fauré-Fremiet, 1924) & $\mathrm{xx}$ & $\mathrm{x}$ & & $\mathrm{x}$ & & $\mathrm{x}$ & $\mathrm{x}$ \\
\hline Saprodinium dentatum (Lauterborn, 1901) & & & & * & $\mathrm{x}$ & & \\
\hline Spathidium spathula (Müller, 1773) & & & & & & & $\mathrm{x}$ \\
\hline Spirostomum minus (Roux, 1901) & & & & $\mathrm{x}$ & $*$ & & $\mathrm{x}$ \\
\hline Spirostomum teres (Claparède, Lachmann, 1858) & $\mathrm{x}$ & $\mathrm{xx}$ & $\mathrm{x}$ & $\mathrm{x}$ & $\mathrm{x}$ & & $\mathrm{x}$ \\
\hline Stentor coeruleus (Pallas, 1766 ) & & $\mathrm{x}$ & & $\mathrm{x}$ & & & $\mathrm{xx}$ \\
\hline Stentor igneus (Ehrenberg, 1838) & & & & & & & $\mathrm{xx}$ \\
\hline
\end{tabular}


Table A1. Cont.

\begin{tabular}{|c|c|c|c|c|c|c|c|}
\hline \multirow{2}{*}{ Sites } & & \multirow{2}{*}{ Pelagial } & & \multicolumn{2}{|c|}{ Bottom } & \multirow{2}{*}{ Metaphytal } & \multirow{2}{*}{ Periphytal of Macrophytes ** } \\
\hline & & & & Littoral & Profundal & & \\
\hline Stentor muelleri (Ehrenberg, 1832) & & & & & & $\mathrm{x}$ & $\mathrm{x}$ \\
\hline Stentor niger (Müller, 1773) & & & & & & & $\mathrm{x}$ \\
\hline Stentor polymorphus (Müller, 1773) & & & & $\mathrm{xx}$ & & $\mathrm{x}$ & $\mathrm{xx}$ \\
\hline Stentor roeselii (Ehrenberg, 1835) & & & & & & & $\mathrm{xx}$ \\
\hline Stichotricha secunda (Perty, 1849) & & & & & & & $\mathrm{x}$ \\
\hline Stokesia vernalis (Wenrich, 1929) & $\mathrm{x}$ & & & & & & $\mathrm{x}$ \\
\hline Strobilidium caudatum (Fromentel, 1876) & $\mathrm{x}$ & $\mathrm{x}$ & & $\mathrm{x}$ & * & $\mathrm{x}$ & $\mathrm{x}$ \\
\hline Strobilidium $\mathrm{sp}$. & $\mathrm{x}$ & $\mathrm{x}$ & & & * & $\mathrm{x}$ & \\
\hline Strombidium sp. & $\mathrm{xx}$ & $\mathrm{x}$ & $*$ & $\mathrm{x}$ & & $\mathrm{x}$ & \\
\hline Strongylidium labiatum (Kahl, 1932) & & & & & & $\mathrm{x}$ & \\
\hline Stylonychia mytilus (Müller, 1773) & & & & $\mathrm{x}$ & & & $\mathrm{xx}$ \\
\hline Stylonychia pustulata (Müller, 1786) & & & & & & & $\mathrm{x}$ \\
\hline Stylonychia sp. & & & & & & & $\mathrm{x}$ \\
\hline Stylonychia vorax (Stokes, 1885) & $\mathrm{x}$ & & & & & & \\
\hline Tachysoma pellionellum (Müller, 1773) & & & & & & & $x x$ \\
\hline Thuricola obconica (Kahl, 1933) & & & & & & & $\mathrm{x}$ \\
\hline Thylakidium truncatum (Schewiakoff, 1893) & $\mathrm{x}$ & & & & & & \\
\hline Tintinnidium fluviatile (Stein, 1863) & $\mathrm{xx}$ & & & & & & \\
\hline Trachelius ovum (Ehrenberg, 1831) & & & & & & & $\mathrm{x}$ \\
\hline Trachelophyllum apiculatum (Perty, 1852) & & & & & & & $\mathrm{x}$ \\
\hline Trachelophyllum sigmoides (Kahl, 1926) & & & & & & & $\mathrm{x}$ \\
\hline Trimyema compressum (Lackey, 1925) & & & $\mathrm{x}$ & & $\mathrm{xx}$ & & \\
\hline Trithigmostoma cucullulus (Müller, 1786) & & & & & & & $\mathrm{x}$ \\
\hline Trithigmostoma sp. & & & & & & & $\mathrm{x}$ \\
\hline Urocentrum turbo (Müller, 1786) & $\mathrm{x}$ & $\mathrm{xx}$ & * & $\mathrm{x}$ & & $\mathrm{x}$ & \\
\hline Uroleptus musculus (Kahl, 1932) & & & & & & & $\mathrm{x}$ \\
\hline Uroleptus piscis (Müller, 1773) & & & & & * & & $\mathrm{x}$ \\
\hline
\end{tabular}


Table A1. Cont.

\begin{tabular}{|c|c|c|c|c|c|c|c|}
\hline \multirow{2}{*}{ Sites } & \multicolumn{3}{|c|}{ Pelagial } & \multicolumn{2}{|c|}{ Bottom } & \multirow[t]{2}{*}{ Metaphytal } & \multirow[t]{2}{*}{ Periphytal of Macrophytes ** } \\
\hline & & & & Littoral & Profundal & & \\
\hline Uronema halophila (Kahl, 1931) & $\mathrm{x}$ & $x x$ & $\mathrm{xx}$ & $\mathrm{xx}$ & $\mathrm{xx}$ & & $\mathrm{x}$ \\
\hline Uronema nigricans (Müller, 1786) & & $\mathrm{x}$ & $\mathrm{x}$ & $\mathrm{x}$ & & & \\
\hline Uronema sp. & $\mathrm{x}$ & & & $\mathrm{x}$ & & $\mathrm{x}$ & \\
\hline Urostyla grandis (Ehrenberg, 1830) & & & & & & & $\mathrm{x}$ \\
\hline Urotricha armata (Kahl, 1927) & $\mathrm{x}$ & $\mathrm{x}$ & & $\mathrm{x}$ & & $\mathrm{x}$ & $\mathrm{x}$ \\
\hline Urotricha farcta (Claparède, Lachmann, 1859) & $\mathrm{xx}$ & & & & & & \\
\hline Urotricha furcata (Schewiakoff, 1892) & $\mathrm{xx}$ & $\mathrm{xx}$ & & $\mathrm{xx}$ & * & $\mathrm{x}$ & $x x$ \\
\hline Urotricha ovata (Kahl, 1926) & $\mathrm{x}$ & & & & & & $\mathrm{x}$ \\
\hline Urotricha pelagica (Kahl, 1935) & $\mathrm{xx}$ & $\mathrm{x}$ & & $\mathrm{x}$ & & $\mathrm{x}$ & $\mathrm{x}$ \\
\hline Urotricha sp. & & & & & & & $\mathrm{x}$ \\
\hline Urotrichopsis saprophila (Kahl, 1930) & & & $\mathrm{x}$ & & & & \\
\hline Vaginicola crystallina (Ehrenberg, 1830) & & & & & & & $\mathrm{x}$ \\
\hline Vaginicola sp. & & & & & & & $\mathrm{x}$ \\
\hline Vorticella campanula (Ehrenberg, 1831) & & & & & & $\mathrm{x}$ & $\mathrm{xx}$ \\
\hline Vorticella convallaria-complex & $\mathrm{x}$ & $\mathrm{x}$ & & & & $\mathrm{x}$ & $\mathrm{xx}$ \\
\hline Vorticella infusionum-complex & & & & & & & $\mathrm{x}$ \\
\hline Vorticella lutea (Stiller, 1938) & & & & $\mathrm{x}$ & & & $\mathrm{x}$ \\
\hline Vorticella microscopica (Fromentel, 1876) & & & & & & & $\mathrm{x}$ \\
\hline Vorticella microstoma-complex & & & $*$ & & & & $\mathrm{x}$ \\
\hline Vorticella sp. & & & & & & & $\mathrm{x}$ \\
\hline Vorticella vernalis (Stokes, 1887) & * & $\mathrm{x}$ & & & & & $\mathrm{x}$ \\
\hline Zoothamnium arbuscula (Ehrenberg, 1831) & & & & & & & $\mathrm{x}$ \\
\hline Zoothamnium simplex (Kent, 1881) & & & & & & & $\mathrm{x}$ \\
\hline
\end{tabular}

Note: $x x-$ frequency of occurrence close to $50 \%$ of samples from the site; $x-$ frequency of occurrence less than $50 \%$ of samples from the site; * - very rare and in very small numbers in the site; ** Macrophytes: Ceratophyllum demersum L., Phragmites australis (Cav.) Trin. ex Steudel, Lemna minor L., Spirodela polyrrhiza (L.) Schleid., Nuphar lutea (L.) Sibth. \& Sm. 


\section{References}

1. Finlay, B.J.; Esteban, G.F. Freshwater protozoa: Biodiversity and ecological function. Biodivers. Conserv. 1998, 7, 1163-1186. [CrossRef]

2. Corliss, J.O. Biodiversity and biocomplexity of the protists and an overview of their significant roles in maintenance of our biosphere. Acta Protozool. 2002, 41, 199-219.

3. Foissner, W.; Chao, A.; Katz, L.A. Diversity and geographic distribution of ciliates (Protista: Ciliophora). Biodivers. Conserv. 2008, 7, 345-363. [CrossRef]

4. Baldock, B.M.; Sleigh, M.A. The ecology of benthic protozoa in rivers: Seasonal variation in numerical abundance in fine sediments. Arch. Hydrobiol. 1988, 111, 409-421.

5. Madoni, P. Community structure and distribution of ciliated Protozoa in a freshwater pond covered by Lemna minor. Boll. Zool. 1991, 58, 273-279. [CrossRef]

6. Foissner, W.; Unterweger, A.; Henschel, T. Comparison of direct stream bed and artificial substrate sampling of Ciliates (Protozoa, Ciliophora) in a mesosaprobic river. Limnologica 1992, 22, 97-104.

7. Sleigh, M.A.; Baldock, B.M.; Baker, J.H. Protozoan communities in chalk streams. Hydrobiology 1992, 248, 53-64. [CrossRef]

8. Finlay, B.J.; Téllez, C.; Esteban, G. Diversity of free-living ciliates in the sandy sediment of a Spanish stream in winter. J. Gen. Microbiol. 1993, 139, 2855-2863. [CrossRef]

9. Babko, R.V.; Kuzmina, T.M. Spatial distribution of ciliates (Protista, Ciliophora) in the River Bityza (Dnieper basin). Vestn. Zool. 1999, 33, 83-89.

10. Babko, R.V.; Kuzmina, T.M. Ciliata (Protista, Ciliophora) of epiphyton of higher aquatic plants in a small River. Hydrobiol. J. 2004, 40, 22-38. [CrossRef]

11. Kovalchuk, A.A. Epyphitic ciliata of the Dnieper reservoirs. Hydrobiol. J. 2001, 3, 45-64.

12. Kreutza, M.; Foissner, W. The Sphagnum Ponds of Simmelried in Germany: A Biodiversity Hot-Spot for Microscopic Organisms. In Protozoological Monographs; Shaker-Publishers: Düren/Maastricht, Germany, 2006; Volume 3, p. 267. ISBN 3-8322-2544-7.

13. Finlay, B.J.; Esteban, G.F. Ubiquitous microbes and ecosystem function. Limnetica 2001, 20, 31-43.

14. Hul, M. Formation of the structure of Ciliata seston communities in the River Lyna (Northern Poland). Acta Hydrobiol. 1987, 29, 203-218.

15. El Serehy, H.A.N.; Sleigh, M.A. Ciliates in the Plankton of the River Itchen Estuary, England. Acta Protozool. 1993, 32, 183-190.

16. Modenutti, B.E.; Balseiro, E.G.; Queimalinos, C.P. Ciliate community structure in two South Andean lakes: The effect of lake water on Ophrydium naumanni distribution. Aquat. Microb. Ecol. 2000, 21, 299-307. [CrossRef]

17. Mazei, Y.A.; Burkovsky, I.V. Vertical structure of the interstitial ciliate community in the Chernaya River estuary (the White Sea). Protistology 2003, 3, 107-120.

18. Mazei, Y.A.; Burkovsky, I.V. Species composition of benthic ciliate community in the Chernaya River estuary (Kandalaksha Bay, White Sea) with a total checklist of the White Sea benthic ciliate fauna. Protistology 2005, 4, 107-120.

19. Mieczan, T. Size spectra and abundance of planktonic ciliates within various habitats in a macrophyte-dominated lake (Eastern Poland). Biologia 2007, 62, 189-194. [CrossRef]

20. Kiss, A.K.; Acs, E.; Kiss, K.T.; Török, J.K. Structure and seasonal dynamics of the protozoan community (heterotrophic flagellates, ciliates, amoeboid protozoa) in the plankton of a large river (River Danube, Hungary). Eur. J. Protistol. 2009, 45, 121-138. [CrossRef]

21. Coyne, K.J.; Countway, P.D.; Pilditch, C.A.; Lee, C.K.; Caron, D.A.; Cary, S.C. Diversity and Distributional Patterns of Ciliates in Guaymas Basin Hydrothermal Vent Sediments. J. Eukaryot. Microbiol. 2013, 60, 433-447. [CrossRef]

22. Yeates, A.M.; Esteban, G.F. Local ciliate communities associated with aquatic macrophytes. Int. Microbiol. 2014, 17, 31-40. [CrossRef] [PubMed]

23. Kammerlander, B.; Koinig, K.A.; Rott, E.; Sommaruga, R.; Tartarotti, B.; Trattner, F.; Sonntag, B. Ciliate community structure and interactions within the planktonic food web in two alpine lakes of contrasting transparency. Freshw. Biol. 2016, 61, 1950-1965. [CrossRef] [PubMed] 
24. Fenchel, T.; Finlay, B.J. Oxygen and the spatial structure of microbial communities. Biol. Rev. 2008, 83, 553-569. [CrossRef] [PubMed]

25. Fenchel, T. Protozoa and Oxygen. Acta Protozool. 2012, 52, 11-20.

26. Babko, R.V. Microbenthometer for protistological studies. Hydrobiol. J. 1989, 25, 78-80. (In Russian)

27. Babko, R.V.; Fyda, J.; Kuzmina, T.; Hutorowicz, A. Ciliates on the macrophytes in industrially heated lakes (Kujawy Lakeland, Poland). Vestn. Zool. 2010, 44, 483-493. [CrossRef]

28. Foissner, W. Basic light and scanning electron microscopic methods for taxonomic studies of Ciliated Protozoa. Europ. J. Protistol. 1991, 27, 313-330. [CrossRef]

29. Kahl, A. Urtiere oder Protozoa I: Wimpertiere oder Ciliata (Infusoria) 1. Allgemeiner Teil und Prostomata. Tierwelt Dtl. 1930, 18, 1-180.

30. Kahl, A. Urtiere oder Protozoa I: Wimpertiere oder Ciliata (Infusoria) 2. Holotricha außer den im 1. Teil behandelten Prostomata. Tierwelt Dtl. 1931, 21, 181-398.

31. Kahl, A. Urtiere oder Protozoa I: Wimpertiere oder Ciliata (Infusoria) 3. Spirotricha. Tierwelt Dtl. 1932, 25, 399-650.

32. Kahl, A. Urtiere oder Protozoa I: Wimpertiere oder Ciliata (Infusoria) 4. Peritricha und Chonotricha. Tierwelt Dtl. 1935, 30, 651-886.

33. Foissner, W.; Berger, H. A user-friendly guide to the ciliates (Protozoa, Ciliophora) commonly used by hydrobiologists as bioindicators in rivers, lakes, and waste waters, with notes on their ecology. Freshw. Biol. 1996, 35, 375-482.

34. Foissner, W.; Blatterer, H.; Berger, H.; Kohmann, F. Taxonomische und Ökologische Revision der Ciliaten des Saprobiensystems. Band I: Cyrtophorida, Oligotrichida, Hypotrichida, Colpodea. Informationsberichte des Bayer; Landesamtes für Wasserwirtschaft: Deggendorf, Germany, 1991; pp. 1-478.

35. Foissner, W.; Berger, H.; Kohmann, F. Taxonomische und Ökologische Revision der Ciliaten des Saprobiensystems. Band II: Peritrichida, Heterotrichida, Odontostomatida. Informationsberichte des Bayer; Landesamtes für Wasserwirtschaft: Deggendorf, Germany, 1992; pp. 1-502.

36. Foissner, W.; Berger, H.; Kohmann, F. Taxonomische und Ökologische Revision der Ciliaten des Saprobiensystems. Band III: Hymenostomatida, Prostomatida, Nassulida. Informationsberichte des Bayer; Landesamtes für Wasserwirtschaft: Deggendorf, Germany, 1994; pp. 1-548.

37. Foissner, W.; Berger, H.; Blatterer, H.; Kohmann, F. Taxonomische und Ökologische Revision der Ciliaten des Saprobiensystems. Band IV: Gymnostomatea, Loxodes, Suctoria. Informationsberichte des Bayer; Landesamtes für Wasserwirtschaft: Deggendorf, Germany, 1995; pp. 1-540.

38. Jankowski, A.W. Morphology and evolution of Ciliophora. III. Diagnoses and phylogenesis of 53 sapropelebionts, mainly of the order Heterotrichida. Arch. Protistenkd. 1964, 107, 185-194.

39. Warren, A. A revision of the genus Vorticella (Ciliophora: Peritrichida). Bull. Br. Mus. Nat. Hist. Zool. 1986, 50, 1-57.

40. Warren, A. A revision of the genus Pseudovorticella Foissner \& Schiffmann, 1974 (Ciliophora: Peritrichida). Bull. Br. Mus. Nat. Hist. Zool. 1987, 52,1-12.

41. R Core Team. R: A Language and Environment for Statistical Computing; R Foundation for Statistical Computing: Vienna, Austria, 2013; Available online: https://www.R-project.org/ (accessed on 15 April 2020).

42. Maechler, M.; Rousseeuw, P.; Struyf, A.; Hubert, M.; Hornik, K. Cluster: Cluster analysis basics and extensions. $R$ Package Version 2012, 1, 56.

43. Kassambara, A.; Mundt, F. Factoextra: Extract and visualize the results of multivariate data analyses. $R$ Package Version 2017, 1, 337-354.

44. Le, S.; Josse, J.; Husson, F. FactoMineR: An R package for multivariate analysis. J. Stat. Softw. 2008, $25,1-18$. [CrossRef]

45. Wickham, H. Ggplot2: Elegant Graphics for Data Analysis; Springer: New York, NY, USA, 2009.

46. Fenchel, T.; Finlay, B.J.; Gianni, A. Microaerophily in ciliates: Responses of an Euplotes species (Hypotrichida) to oxygen tension. Arch. Protistenkd. 1989, 137, 317-330. [CrossRef]

47. Fenchel, T.; Bernard, C. Behavioural responses in oxygen gradients of ciliates from microbial mats. Eur. J. Protistol. 1996, 32, 55-63. [CrossRef] 
48. Babko, R.V. Communities of Free-Living Ciliated Protozoa (Chromista, Ciliophora) of Continental Waters. Thesis, D.Sci. of biol. sci., Institute of Hydrobiology, National Academy of Sciences of Ukraine, Kyiv, Ukraine, 2019. (In Ukrainian).

49. Ricklefs, R.E. Disintegration of the Ecological Community. Am. Nat. 2008, 172, 741-750. [CrossRef]

50. Vellend, M. Conceptual synthesis in community ecology. Q. Rev. Biol. 2010, 85, 183-206. [CrossRef] [PubMed]

51. Burkovsky, I.V. Ecology of Free-Living Ciliates; Moscow State University: Moscow, Russia, 1984; p. 208. (In Russian)

52. Burkovsky, I.V. Structural and Functional Organization and Stability of Marine Communities (on the Example of the White Sea Sand Littoral); Moscow State University: Moscow, Russia, 1992; p. 208. (In Russian)

53. Alekperov, I.K. Free-living ciliates of Azerbaijan (ecology, zoogeography, practical value). In Monograph; Elm: Baku, Azerbaijan, 2012; p. 520. (In Russian)

54. Dubrovsky, Y.V.; Kovalchuk, A.A.; Monchenko, V.I.; Mylnikov, A.P. On the composition of the animal population in the hollows of trees of the Girkan Reserve (Azerbaijan). Biodiversity and the role of animals in ecosystems. In Proceedings of the Materials of the VII International Scientific Conference, Dnipropetrovsk, Ukraine, 22-25 October 2013; Adverta: Dnipropetrovsk, Ukraine, 2013; pp. 50-52. (In Russian).

55. Kovalchuk, A.A. Infusoria of fish-breeding ponds of the Kiev region. III. Benthos. Fish. Sci. Ukr. 2012, 3, 27-38. (In Russian)

56. Kovalchuk, A.A. Infusoria of fish-breeding ponds of the Kiev region. I. Plankton. Fish. Sci. Ukr. 2012, 2, 31-44. (In Russian)

57. Blatterer, H.; Foissner, W. Morphology and infraciliature of some cyrtophorid ciliates (Protozoa, Ciliohora) from freshwater and soil. Arch. Protistenkd. 1992, 14, 101-118. [CrossRef]

58. Bonatti, T.R.; Siqueira-Castro, I.C.V.; Franco, R.M.B. Checklist of ciliated protozoa from surface water and sediment samples of Atibaia River, Campinas, São Paulo (Southeast Brazil). Rev. Bras. Zoocienc. 2016, 17, 63-76.

59. Bereczky, M.C. Die ökologische Charakterisierung einiger Ciliaten-Organismen des ungarischen Donauabschnittes. Annls Univ. Sci. Bpest. 1975, 17, 123-136.

60. Detcheva, R.B. Distribution des especes de cilies dans certains affluents Bulgares du Danube, aux eaux polluees. Annls Stn. Limnol. 1972, 6, 261-269.

61. Detcheva, R.B. Caracteristiques ecologiques des cilies de la riviere Maritza. Annls Stn. Limnol. 1983, 16, 200-219.

62. Patrick, R.; Cairns, J., Jr.; Roback, S.S. An ecosystematic study of the fauna and flora of the Savannah River. Proc. Acad. Nat. Sci. Phila. 1967, 118, 109-407.

63. Foissner, W.; Adam, H.; Foissner, I. Daten zur Autökologie der Ciliaten stagnierender Kleingewässer im Grossglocknergebiet (Hohe Tauern, Österreich). Ber. Nat. Med. Ver. Salzburg 1982, 6, 81-101.

64. Wilhelm, S. Die Lebensgemeinschaften der Swist im Verlauf der Selbstreinigung. Arch. Hydrobiol. 1964, 60, 89-106.

65. Bick, H.; Kunze, S. Eine Zusammenstellung von autökologischen und saprobiologischen Befunden an Süsswasserciliaten. Int. Rev. Ges. Hydrobiol. 1971, 56, 337-384. [CrossRef]

66. Detcheva, R. Paramètres saprobiologiques et hydrochimiques pour les ciliés de certains affluents Bulgares de la Mer Noire. Hydrobiology 1979, 9, 57-73.

67. Mihailowitsch, B. Taxonomische und Ökologische Untersuchungen an Ciliaten (Protozoa, Ciliophora) in Solebelasteten Fliessgewässern. Ph.D. Thesis, Universität Bonn, Bonn, Germany, 1989.

68. Neidl, F. Die Räumliche und Zeitliche Verteilung des Ciliaten Spirostomum teres im Benthal und Pelagial des Piburger Sees (Tirol, Österr.) Während und Nach der Sommerschichtung. Master's Thesis, Universität Innsbruck, Innsbruck, Austria, 1989.

69. Reck, E.M. Zur Ökologie der Pelagischen Ciliaten des Plußsees. Ph.D. Thesis, Christian-Albrechts-Universität, Kiel, Germany, 1987.

70. Foissner, W.; Wilbert, N. Morphologie, Infraciliatur und Ökologie der limnischen Tintinnina: Tintinnidium fluviatile Stein, Tintinnidium pusillum Entz, Tintinnopsis cylindrata Daday und Codonella cratera (Leidy) (Ciliophora, Polyhymenophora). J. Protistol. 1979, 26, 90-103.

71. Sládeček, V.; Sládecková, A. The plankton community of the Hamry and Sec reservoirs after the spring overturn. Sb. Vys. Sk. Chem. Technol. Praze (Technol. Water) 1962, 6, 389-405. 
72. Schönborn, W. Die Ziliatenproduktion in der mittleren Saale. Limnologica 1982, 14, 329-345.

73. Bick, H. Ciliated Protozoa. An Illustrated Guide to the Species Used as Biological Indicators in Freshwater Biology; World Health Organization: Geneva, Switzerland, 1972; 198p.

74. Detcheva, R.B. Les cilies de la riviere Kamtchia a l'eau polluee. Annls Stn. Limnol. 1976, 10, $299-304$.

75. Detcheva, R.B. Aspects ecologiques des cilies de la riviere Mesta. Annls Stn. Limnol. 1978, 11, 300-309.

76. Detcheva, R.B. L'influence de la pollution sur la distribution des ciliés (Protozoa-Ciliata) de la rivière de Vit-affluent Bulgare du Danube. Hidrobiologia 1983, 17, 348-361.

77. Detcheva, R.B. Distribution des ciliés (Protozoa-Ciliata) par rapport à la pollution hydrochimique de la rivière d’Ossâm-affluent Bulgare du Danube. Hidrobiologia 1983, 17, 362-380.

78. Madoni, P.; Ghetti, P.F. Ciliated protozoa and water quality in the Torrente Stirone (Northern Italy). Acta hydrobiol. 1981, 23, 143-154.

(C) 2020 by the authors. Licensee MDPI, Basel, Switzerland. This article is an open access article distributed under the terms and conditions of the Creative Commons Attribution (CC BY) license (http://creativecommons.org/licenses/by/4.0/). 